\title{
The distribution of radionuclides and some trace metals in the water columns of the Japan and Bonin trenches
}

\author{
Yoshiyuki NOZAKI $^{\text {a*}}$, Masatoshi YAMADA ${ }^{\text {a,c }}{ }^{\text {, Takashi NAKANISHI }}{ }^{\mathrm{b}}$, Yutaka NAGAYA $^{\mathrm{c}}$, \\ Kiyoshi NAKAMURA ${ }^{\mathfrak{c}}$, Kiminori SHITASHIMA ${ }^{d}$, Hiroyuki TSUBOTA ${ }^{\mathrm{d}}$ \\ ${ }^{a}$ The Ocean Research Institute, University of Tokyo, Nakano-ku, Tokyo 164, Japan \\ ${ }^{b}$ Department of Chemistry, Kanazawa University, Kanazawa 920-11, Japan \\ ${ }^{c}$ National Institute of Radiological Sciences, Hitachinaka, Ibaraki 311-12, Japan \\ ${ }^{\mathrm{d}}$ Faculty of Integrated Arts and Sciences, Hiroshima University, Hiroshima 730, Japan
}

(Received 10/06/97, revised 21/08/97, accepted 12/09/97)

\begin{abstract}
Presented here is the first detailed geochemical data set on the U/Th series $\mathrm{Th}, \mathrm{Pa}, \mathrm{Ac}$, and $\mathrm{Pb}$ isotopes and artificial fallout radionuclides $\left({ }^{90} \mathrm{Sr},{ }^{137} \mathrm{Cs}\right.$, and $\mathrm{Pu}$ isotopes), and some trace elements ( $\mathrm{V}, \mathrm{Zn}, \mathrm{Cd}, \mathrm{Cu}, \mathrm{Mn}$, and $\mathrm{Ni}$ ) in two water columns of the Japan and Bonin trenches down to the bottom depths of $7585 \mathrm{~m}$ and $9750 \mathrm{~m}$, respectively. Hydrographic properties such as temperature, salinity, dissolved oxygen, and nutrient content within the trench valley remain constant at the same levels as those in the bottom water of the Northwest Pacific basin (typically $\sim 6000 \mathrm{~m}$ in depth). The radionuclide activities and most trace metal concentrations are also not very different from those in the overlying water at depths of around $5000-6000 \mathrm{~m}$. This means that any chemical alteration which sea water undergoes during its residence within the trench was not obviously detected by the techniques used here. The suggestion follows that the trench water is rather freely communicating by isopyenal mixing with the bottom water overlying the Northwest Pacific abyssal plain. The trench waters contain high ${ }^{239,}{ }^{240} \mathrm{Pu}$ activities throughout, indicating that $\mathrm{Pu}$ is actively regenerating from rapidly sinking, large particles at the bottom interface, probably due to a change in the oxidation state. On the other hand, the vertical profiles of ${ }^{210} \mathrm{~Pb}$ and ${ }^{231} \mathrm{~Pa}$ show lower activities within the trench than those in the overlying deep waters, suggesting that the effect of boundary and bottom scavenging is significant in controlling their oceanic distributions. However, none of the trace metals studied here obviously follows the behaviour of the above nuclides. The ${ }^{228} \mathrm{Th}$ data show scattering within the Bonin Trench that is largely ascribable to analytical errors. If, however we accept that the scatter of ${ }^{228} \mathrm{Th}$ data is real and the variation is caused solely by decay of its parent ${ }^{228} \mathrm{Ra}$, we can set an upper limit of $\sim 5$ years for the renewal time of the trench water. (C) Elsevier, Paris
\end{abstract}

U/Th series nuclides / artificial radionuclides / scavenging / trace metals / renewal of trench water

Résumé - Répartition des nucléides radioactifs et de quelques métaux-traces dans les fosses du Japon et des îles Bonin. La première série détaillée de données géochimiques obtenues dans deux colonnes d'eau des fosses du Japon et des îles Bonin, respectivement jusqu'à 7585 m et 9750 m, est présentée ici. Elle porte sur la série uranium/thorium, sur les isotopes de thorium, protactinium, actinium et plomb et sur les retombées des nucléides radioactifs artificiels (strontium-90, césium-137 et plutonium) ainsi que sur quelques éléments à l'état de traces (vanadium, zinc, cadmium, cuivre, manganèse et nickel). Les caractéristiques hydrologiques telles que température, salinité, oxygène dissous et teneurs en nutriments prennent les mêmes valeurs aux mêmes profondeurs, dans les fosses comme dans l'eau de fond du bassin nord-occidental du Pacifique (typiquement, vers $6000 \mathrm{~m}$ ). De même, les valeurs de l'activité des nucléides radioactifs et les concentrations

* Correspondence and reprints. 
de la plupart des traces métalliques ne sont pas très différentes dans la fosse et dans l'eau sus-jacente, vers $5000-6000 \mathrm{~m}$. $\mathrm{Si}$, au cours de son transit dans la fosse, l'eau a subi une modification chimique, celle-ci n'a pas été détectée par les techniques utilisées. Cela suggère que l'eau de la fosse communique assez librement par mélange isopycne avec l'eau de fond qui couvre la plaine abyssale dans le nord-ouest du Pacifique. Partout dans les eaux de la fosse l'activité du ${ }^{239,240} \mathrm{Pu}$ est élevée, ce qui indique que le plutonium est activement régénéré à partir des grosses particules qui sédimentent rapidement sur le fond, probablement par un changement de leur état d'oxydation. De plus les profils verticaux de ${ }^{210} \mathrm{~Pb}$ et ${ }^{231} \mathrm{~Pa}$ indiquent des activités plus faibles dans la fosse que dans les eaux profondes sus-jacentes, suggérant que l'effet de barrière et le balayage sur le fond sont significatifs dans la répartition de ces éléments dans l'océan. Aucun des éléments-traces étudiés ici ne se comporte comme les nucléides radioactifs. Dans la fosse des îles Bonin, les données de ${ }^{228}$ Th montrent une dispersion qui est due essentiellement aux erreurs analytiques. Cependant, si la dispersion est réelle et résulte uniquement de la désintégration du ${ }^{228} \mathrm{Ra}$, on peut fixer une limite supérieure d'environ cinq ans pour le temps de renouvellement de l'ean dans la fosse. (C) Elsevier, Paris

uranium - thorium / nucléide artificiel / balayage / métal-trace / temps de résidence

\section{INTRODUCTION}

The purpose of this paper is to describe the first detailed measurements of radionuclides and some chemical constituents in the water columns of the Japan and Bonin (also called "Izu-Ogasawara") trenches, together with their geochemical implications. Trenches, defined as narrow valley features of the ocean floor exceeding $7000 \mathrm{~m}$ in depth, are located along the plate boundaries where one plate is subducting under the other. Although trench regions occupy only $\sim 1.2 \%$ of the ocean floor, their near-bottom environments are attractive to marine scientists working in various disciplines as subjects of investigation. To date, however, hydrographic and geochemical investigations have been few. For example, during the Southern Cross Expedition of the R.V. Hakuho-Maru in 1968-69 [13], a hydrocast was made with Nansen bottles down to $\sim 10000 \mathrm{~m}$ in the Tonga Trench, but all the reversing thermometers reaching depths greater than $8000 \mathrm{~m}$ were broken due to high water pressure. The GEOSECS expeditions between the 1970s and early 1980s occupied numerous stations in the world oceans, but samples were obtained at only two stations in the South Sandwich and Aleutian Trenches down to a maximum depth of $7800 \mathrm{~m}$ [45]. No other attempts have been reported so far, and therefore the oceanographic environment of the super-deep (e.g. $>8000 \mathrm{~m}$ ) oceanic trenches remains virtually unexplored.

Fractional but plausible evidence available up to now suggests that active particle transport is laking place within the trench valley [32], and that relatively high biomass is sustained there [38]. The 1984 R.V. Hakuho-Maru Cruise (called the Antares Expedition) was aimed at collecting geochemical data in the deepest parts of the Japan and Izu-Ogasawara trenches. The results indicate that the water within the trench is relatively uniform, with chemical characteristics which are not very different from those of overlying water in the adjacent abyssal plain around the depth of $\sim 6000 \mathrm{~m}$.

\section{MATERIALS AND METHODS}

\subsection{Sampling}

Two stations in the Japan and Izu-Ogasawara (also called Bonin) trenches were occupied by the Antares Expedition (KH 84-3 R.V. Hakuho-Maru Cruise) from August to September 1984. Figure I shows the bottom topography and the station locations. The bottom depth is $9750 \mathrm{~m}$ for $\mathrm{AN}-1$ and $7585 \mathrm{~m}$ for AN-4. A tapered steel wire $(9 \mathrm{~mm}$ diameter at the top and $14 \mathrm{~mm}$ at the end of its $14000 \mathrm{~m}$ length) was used for all large-volume water sampling and Niskin bottle casts deeper than $7000 \mathrm{~m}$. Water temperature was measured using specially designed reversing glass thermometers available at that time for use in depths of up to $11000 \mathrm{~m}$. Samples for measurements of salinity, dissolved oxygen, $\mathrm{pH}$, nutrients, and ${ }^{210} \mathrm{~Pb}$ were obtained by standard $23 \mathrm{~L}$ Niskin bottles. For trace metals, either the Cal-Tech.-type [41] or the TsubotaKanamori-Murozumi beloze-type polyethylene bag samplers [16] were used. For radionuclide measurements, large-volume water samples were obtained by using a twin $270 \mathrm{~L}$ PVC-bottle sampler.

At the same time, suspended particulate matter and dissolved actinides adsorbable on $\mathrm{MnO}_{2}$-impregnated fiber 




Figure 1. Sampling locations in the Japan and Izu-Ogasawara trenches during the Antares R.V. Hakuho-Maru Expedition. The JT site is the location where sediment-trap experiments have been carried out since 1986.

were also collected using battery-powered large-volume in situ pumps. Details of the sampling technique and analysis together with implications of Th isotope data are given in Nozaki et al. [31]. In addition, sediment-trap experiments using Honjo type time-series traps [12] have been carried out at JT site of the northern Izu-Ogasawara Trench (figure 1). Details of the experiments are given elsewhere [26].

\subsection{Analysis}

The analytical procedure for trace metals is described in detail by Shitashima [43]. Trace metals were concentrated using a chelex-100 column chromatography and determined by graphite furnace atomic absorption spectrometry. Since some deionized and distilled water was used for sampling, the results were suitably corrected for dilution effect based on salinity measurements.
${ }^{210} \mathrm{~Pb}$ was determined using $\sim 3 \mathrm{~L}$ aliquots of unfiltered sea water obtained using Niskin bottles. The analysis was performed 2.5 years after the sampling, during which time ${ }^{210} \mathrm{Po}$ had reached equilibrium with ${ }^{210} \mathrm{~Pb}$. The procedure of Nozaki [25] which was followed includes coprecipitation of ${ }^{210} \mathrm{Po}$ with iron-hydroxide, isolation by electrodeposition onto a silver disc, and subsequent $\alpha$-spectroscopy, using ${ }^{208} \mathrm{Po}$ as a yield monitor.

All the radionuclides except ${ }^{210} \mathrm{~Pb}$ were determined using $\sim 250 \mathrm{~L}$ water samples according to the method described in Nozaki [28]. 'The unfiltered water was acidified and degassed by purging nitrogen gas in order to extract $\mathrm{CO}_{2}$ for radiocarbon measurement. Then appropriate amounts of ${ }^{234} \mathrm{Th},{ }^{233} \mathrm{~Pa},{ }^{242} \mathrm{Pu}$, and common $\mathrm{Cs}$ and $\mathrm{Fe}$ were added to the water and thoroughly mixed. The actinides and $\mathrm{Pu}$ in the solution were coprecipitated with iron hydoxide by neutralizing the water with ammonia. The hydroxide was removed from the water and redissolved in $8 \mathrm{M} \mathrm{HNO}_{3}$ solution. $\mathrm{Th}, \mathrm{Pa}, \mathrm{Pu}$, and $\mathrm{Ac}$ isotopes were successively separated by the ion-exchange procedure and determined by $\alpha$-spectrometry according to the methods described earlier ([30] for $\mathrm{Th}$ and $\mathrm{Pa}$, [32] for $\mathrm{Ac}$, [23] for $\mathrm{Pu}$ ). The procedures for ${ }^{137} \mathrm{Cs}$ and ${ }^{90} \mathrm{Sr}$ in the remaining sea water, described in Nagaya and Nakamura [22], include coprecipitations of ${ }^{137} \mathrm{Cs}$ with ammonium molihdophosphate and ${ }^{90} \mathrm{Sr}$ with calcium carbonate, followed by chemical purification and $\beta$ assay of the two nuclides.

\section{RESULTS}

\subsection{Hydrographic data}

The vertical profiles of potential temperature, salinity, dissolved oxygen, and nutrients at the two locations are shown in figure 2. The AN-1 Bonin Trench station is located in the oligotrophic Kuroshio Current regime. A distinct salinity minimum, which is a characteristic of the North Pacific Intermediate Water, can be clearly seen centered around $700 \mathrm{~m}$. The dissolved oxygen minimum, and nitrate and phosphate maxima, occur around $1250 \mathrm{~m}$. The AN-4 Japan Trench station, on the other hand, is located in the Oyashio Current regime of relatively high productivity. The distinctively low salinity $(S=\sim 33.2$ ) and low temperature $\left(\mathrm{T}=\sim 3{ }^{\circ} \mathrm{C}\right)$ compared to the Kuroshio surface water $\left(\mathrm{S}=34.6-34.7, \mathrm{~T}=18-20^{\circ} \mathrm{C}\right)$ appears at about $100 \mathrm{~m}$ depth (figure 3 ). The surface waters at the two stations have very low nutrient contents, but a notable difference is that the vertical gradient of the nutrients 

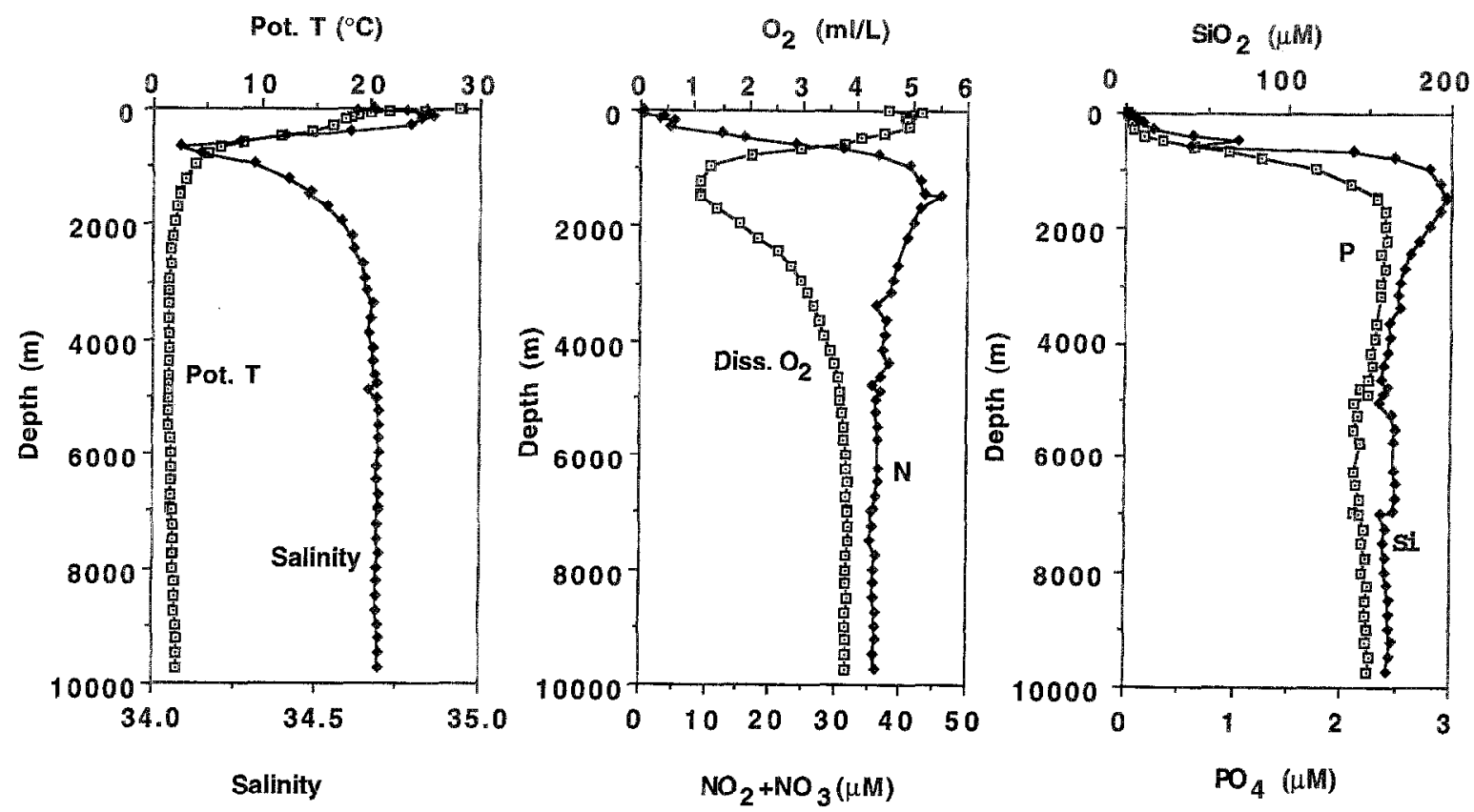

(a)
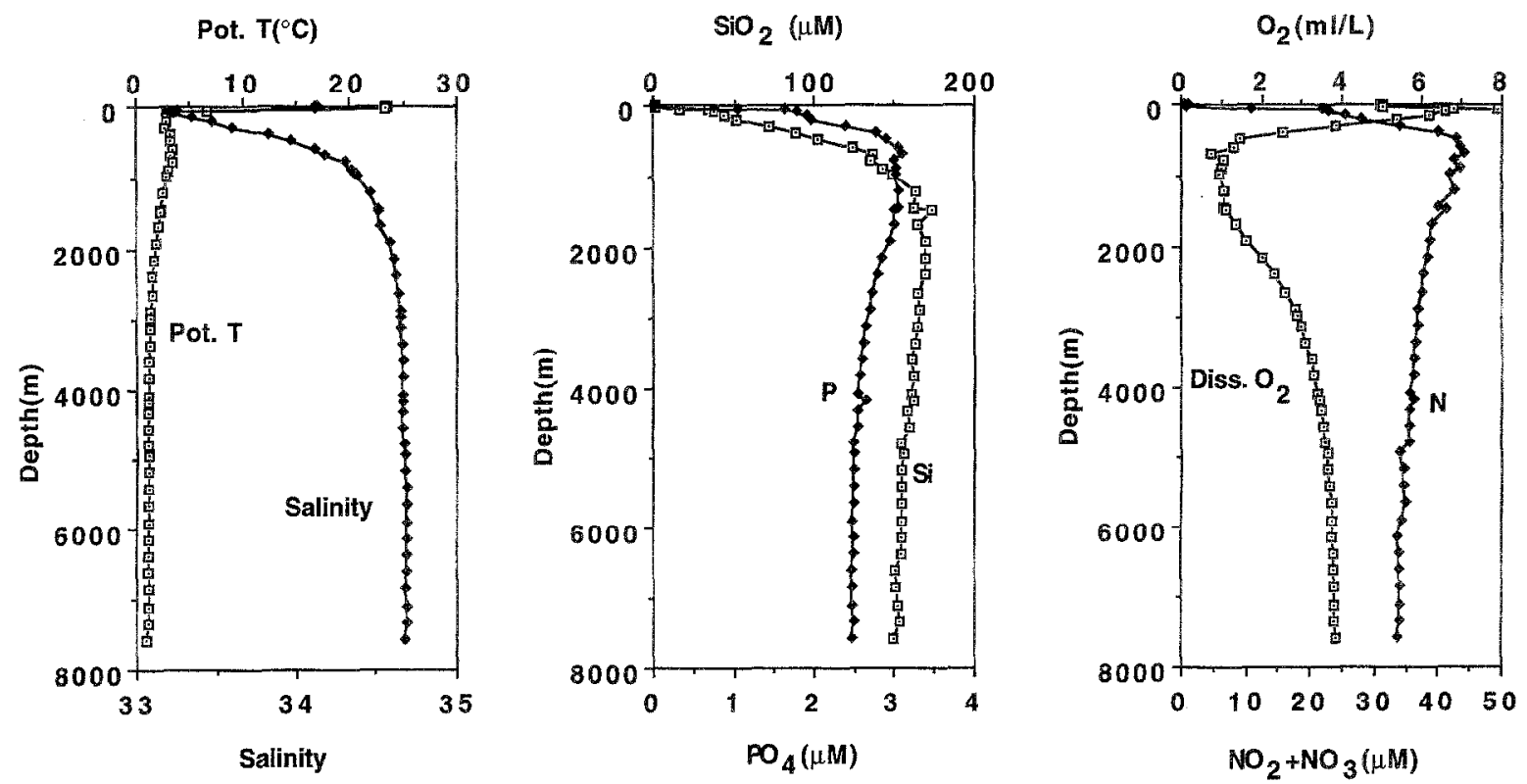

(b)

Figure 2. Vertical profiles of temperature, salinity, dissolved oxygen, nitrate+nitrite, reactive phosphate, and silicate at stations AN-1 (a) and AN-4 (b). 

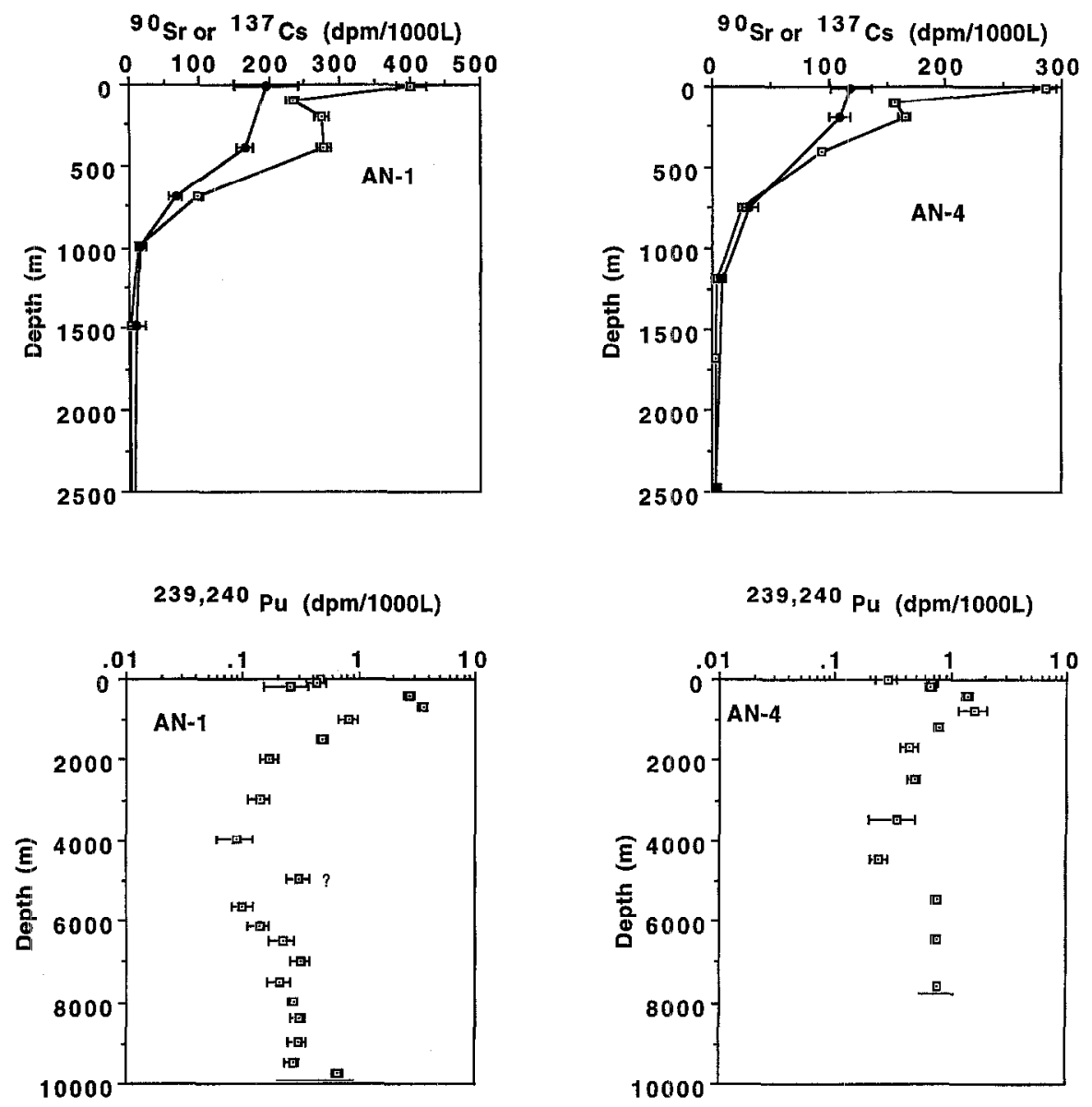

Figure 3. ${ }^{90} \mathrm{Sr}$ and ${ }^{137} \mathrm{Cs}$ in the upper water columns of stations $\mathrm{AN}-1$ and $\mathrm{AN}-4$ (a) and vertical profiles of ${ }^{239}$, 240 $\mathrm{Pu}$ at stations $\mathrm{AN}-1$ and $\mathrm{AN}-4$ (b).

across the seasonal thermocline is much higher at station AN-4 than at station AN-1.

In the deep waters between $5000 \mathrm{~m}$ and the bottom, all the hydrographic properties show very little vertical variation. There is no density stratification in the waters inside the two trenches.

\subsection{Radionuclide data}

Radionuclide data are given in tables $I-I I I$ together with $1 \sigma$ counting errors. ${ }^{231} \mathrm{~Pa},{ }^{227} \mathrm{Ac}$ and ${ }^{210} \mathrm{~Pb}$ were analyzed only at station AN-1 in the Bonin Trench. The analyses of the natural U/Th series nuclides were done in the ORI laboratory at the University of Tokyo. The artificial nuclides, ${ }^{90} \mathrm{Sr}$ and ${ }^{137} \mathrm{Cs}$, and $\mathrm{Pu}$ at Station $\mathrm{AN}-4$ were analyzed at Nakaminato Branch of NIRS, and $\mathrm{Pu}$ at station AN-1 were measured at Kanazawa University. Since unfiltered water was used for the analysis, the data should be regarded as "acid-soluble" activities in the water. However, they probably represent total activities in the water because the Th data which indicated the largest particulate fraction among the nuclides showed good agreement with dissolved-plus-particulate Th determined independently by using large-volume in situ pumps at the two locations [35].

We are somewhat hesitant to present the non-radiogenic ${ }^{232} \mathrm{Th}$ data because of their large uncertainties. Since the contamination problem during handling of the large- 
Table I. The activities of some actinides and artificial radionuclides in the water column of the Izu-Ogasawara Trench.

\begin{tabular}{|c|c|c|c|c|c|c|c|c|}
\hline $\begin{array}{l}\text { Depth } \\
\text { (m) }\end{array}$ & $\begin{array}{c}\text { Th-232 } \\
\text { dpm/1000L }\end{array}$ & $\begin{array}{c}\text { Th-230 } \\
\text { dpm/1000L }\end{array}$ & $\begin{array}{c}\text { Th-228 } \\
\text { dpm/1000L }\end{array}$ & $\begin{array}{c}\mathrm{Pa}-231^{*} \\
\mathrm{dpm} / 1000 \mathrm{~L}\end{array}$ & $\begin{array}{c}\mathrm{Ac}-227^{*} \\
\mathrm{dpm} / 1000 \mathrm{~L}\end{array}$ & $\begin{array}{c}\text { Sr-90* } \\
\operatorname{dpm} / 1000 \mathrm{~L}\end{array}$ & $\begin{array}{c}\mathrm{Cs}-137^{*} \\
\mathrm{dpm} / 1000 \mathrm{~L}\end{array}$ & $\begin{array}{l}\text { Pu-239,240 } \\
\mathrm{dpm} / 1000 \mathrm{~L}\end{array}$ \\
\hline 10 & $0.06 \pm 0.03$ & $0.10 \pm 0.06$ & $4.87 \pm 0.34$ & ND & $0.23=0.06$ & $195 \pm 46$ & $401 \pm 22$ & $0.47 \pm 0.02$ \\
\hline 98 & $0.12 \pm 0.04$ & $0.21 \pm 0.05$ & $2.70 \pm 0.18$ & $0.19 \pm 0.06$ & ND & $\mathrm{ND}$ & $233 \pm 9.3$ & $0.43 \pm 0.08$ \\
\hline 196 & $0.11 \pm 0.04$ & $0.23 \pm 0.06$ & $3.09 \pm 0.22$ & $0.18 \pm 0.09$ & $0.20 \pm 0.05$ & ND & $273 \pm 9.3$ & $0.43 \pm 0.08$ \\
\hline 396 & $0.21 \pm 0.05$ & $0.51 \pm 0.08$ & $3.66 \pm 0.26$ & $0.28 \pm 0.13$ & $0.40 \pm 0.04$ & $164 \pm 12$ & $276 \pm 9.8$ & $2.72 \pm 0.29$ \\
\hline 693 & $0.10 \pm 0.03$ & $0.32 \pm 0.06$ & $2.85 \pm 0.21$ & $0.41 \pm 0.08$ & $0.24 \pm 0.03$ & $66 \pm 9$ & $97 \pm 6.0$ & $3.58 \pm 0.29$ \\
\hline 992 & $0.03 \pm 0.02$ & $0.35 \pm 0.10$ & $0.82 \pm 0.19$ & $0.39 \pm 0.15$ & $0.29 \pm 0.05$ & $16 \pm 7$ & $13 \pm 2.9$ & $0.82 \pm 0.15$ \\
\hline 1488 & $0.05 \pm 0.02$ & $0.53 \pm 0.09$ & $0.53 \pm 0.13$ & $0.51 \pm 0.10$ & $0.32 \pm 0.05$ & $9 \pm 13$ & $3.1 \pm 1.6$ & $0.48 \pm 0.05$ \\
\hline 1990 & $0.07 \pm 0.03$ & $0.55 \pm 0.11$ & $0.60 \pm 0.14$ & $0.40 \pm 0.07$ & $0.39 \pm 0.05$ & ND & ND & $0.17 \pm 0.03$ \\
\hline 2985 & $0.09 \pm 0.05$ & $0.86 \pm 0.17$ & $0.59 \pm 0.22$ & $0.53 \pm 0.13$ & $0.44 \pm 0.04$ & $\mathrm{ND}$ & $2.9 \pm 1.6$ & $0.14 \pm 0.03$ \\
\hline 3971 & $0.06 \pm 0.03$ & $1.18 \pm 0.15$ & $0.89 \pm 0.17$ & $0.58 \pm 0.10$ & $0.90 \pm 0.07$ & $6 \pm 6$ & $3.3 \pm 2.0$ & $0.09 \pm 0.03$ \\
\hline 4964 & $0.10 \pm 0.05$ & $1.36 \pm 0.16$ & $1.62 \pm 0.20$ & $0.79 \pm 0.11$ & $1.30 \pm 0.10$ & ND & $2.0 \pm 1.8$ & $0.31 \pm 0.07$ \\
\hline 5624 & $0.08 \pm 0.04$ & $1.47 \pm 0.20$ & $1.55 \pm 0.24$ & $0.45 \pm 0.09$ & $1.77 \pm 0.12$ & ND & $1.8 \pm 2.0$ & $0.10 \pm 0.02$ \\
\hline 6125 & $0.11 \pm 0.04$ & $1.74 \pm 0.18$ & $2.38 \pm 0.22$ & $0.58 \pm 0.15$ & $1.38 \pm 0.11$ & $1 \pm 8$ & $1.8 \pm 2.0$ & $0.14 \pm 0.03$ \\
\hline 6473 & $0.02 \pm 0.02$ & $1.08 \pm 0.18$ & $1.43 \pm 0.26$ & $0.40 \pm 0.09$ & $1.57 \pm 0.11$ & ND & $6.2 \pm 1.8$ & $0.22 \pm 0.05$ \\
\hline 6971 & $0.05 \pm 0.02$ & $1.22 \pm 0.13$ & $1.97 \pm 0.19$ & $0.41 \pm 0.10$ & $1.54 \pm 0.15$ & ND & $0.0 \pm 0.2$ & $0.32 \pm 0.06$ \\
\hline 7470 & $0.07 \pm 0.04$ & $1.60 \pm 0.22$ & $2.34 \pm 0.32$ & $0.23 \pm 0.04$ & $1.55 \pm 0.17$ & $\mathrm{ND}$ & $3.3 \pm 1.6$ & $0.21 \pm 0.05$ \\
\hline 7968 & $0.04 \pm 0.03$ & $1.55 \pm 0.17$ & $2.41 \pm 0.24$ & $0.40 \pm 0.09$ & $1.50 \pm 0.11$ & $-2 \pm 17$ & $0.2 \pm 1.8$ & $0.27 \pm 0.02$ \\
\hline 8381 & $0.06 \pm 0.03$ & $1.21 \pm 0.16$ & $1.84 \pm 0.22$ & $0.31 \pm 0.09$ & $1.69 \pm 0.11$ & ND & $1.1 \pm 1.6$ & $0.30 \pm 0.04$ \\
\hline 8980 & $0.06 \pm 0.03$ & $1.34 \pm 0.19$ & $2.29 \pm 0.30$ & $0.52 \pm 0.11$ & $1.40 \pm 0.10$ & $5 \pm 5$ & $1.1 \pm 1.8$ & $0.30 \pm 0.05$ \\
\hline 9470 & $0.04 \pm 0.03$ & $1.09 \pm 0.23$ & $1.66 \pm 0.32$ & $0.55 \pm 0.12$ & $\mathrm{ND}$ & $-2 \pm 6$ & $4.0 \pm 3.3$ & $0.27 \pm 0.04$ \\
\hline 9738 & $0.12 \pm 0.06$ & $1.60 \pm 0.24$ & $2.59 \pm 0.37$ & $0.59 \pm 0.20$ & $1.36 \pm 0.12$ & $-3 \pm 8$ & $2.2 \pm 1.6$ & $0.67 \pm 0.07$ \\
\hline
\end{tabular}

*ND : not determined.

Table II. ${ }^{210} \mathrm{~Pb}$ in the water column of the Izu-Ogasawara Trench.

\begin{tabular}{rccc}
\hline $\begin{array}{c}\text { Depth } \\
(\mathbf{m})\end{array}$ & $\begin{array}{c}\text { Pb-210 } \\
\mathbf{d p m} / \mathbf{1 0 0 0 L}\end{array}$ & $\begin{array}{c}\text { Depth } \\
(\mathbf{m})\end{array}$ & $\begin{array}{c}\text { Pb-210 } \\
\mathbf{d p m} / \mathbf{1 0 0 0 L}\end{array}$ \\
\hline 0 & $168 \pm 8$ & 5992 & $122 \pm 6$ \\
483 & $142 \pm 7$ & 6234 & $166 \pm 8$ \\
967 & $161 \pm 8$ & 7001 & $153 \pm 8$ \\
1707 & $185 \pm 9$ & 7250 & $153 \pm 8$ \\
1951 & $164 \pm 8$ & 7500 & $163 \pm 8$ \\
2195 & $199 \pm 10$ & 7749 & $126 \pm 6$ \\
2682 & $194 \pm 10$ & 7998 & $126 \pm 6$ \\
2926 & $186 \pm 9$ & 8247 & $139 \pm 7$ \\
3170 & $225 \pm 11$ & 8496 & $153 \pm 8$ \\
3558 & $195 \pm 10$ & 8745 & $126 \pm 6$ \\
4145 & $192 \pm 10$ & 8995 & $144 \pm 7$ \\
4633 & $178 \pm 9$ & 9244 & $155 \pm 8$ \\
5267 & $152 \pm 8$ & 9493 & $127 \pm 6$ \\
5750 & $138 \pm 7$ & 9742 & $120 \pm 6$ \\
\hline
\end{tabular}

volume sea water samples was not corrected, these values should be regarded as the upper limit. Nevertheless, the ${ }^{232} \mathrm{Th}$ data seem to show higher concentrations in the upper waters than in deep and bottom waters. The deep waters below $2000 \mathrm{~m}$ at station $\mathrm{AN}-4$ have the ${ }^{232} \mathrm{Th}$ mean concentration of $0.03 \pm 0.01 \mathrm{dpm} 10^{-3} \mathrm{~L}$, which is discernibly lower than the mean value of $0.06 \pm$
$0.03 \mathrm{dpm} 10^{-3} \mathrm{~L}$ at the AN-1 site. Since Nozaki et al. [35] have shown that $17-72 \%$ of the total ${ }^{232} \mathrm{Th}$ is present in particulate forms at these locations, dissolved ${ }^{232} \mathrm{Th}$ may be significantly lower than the total given here. The ${ }^{230} \mathrm{Th}$ and ${ }^{23} \mathrm{~Pa}$ activities are two or three orders of magnitude lower than those of parent ${ }^{234} \mathrm{U}$ and ${ }^{235} \mathrm{U}$, respectively. They show systematic increase with depth down to $\sim 6000 \mathrm{~m}$, while the ${ }^{228} \mathrm{Th}$ concentrations become the lowest around $2000 \mathrm{~m}$ to $3000 \mathrm{~m}$ with higher concentrations in the surface and near-bottom waters. The mean activities in the trench waters $(>6000 \mathrm{~m})$ are nearly the same for the AN-1 and AN-4 sites at $1.4 \mathrm{dpm} 10^{-3} \mathrm{~L}$ for ${ }^{230} \mathrm{Th}$ and $2.2 \mathrm{dpm} 10^{-3} \mathrm{~L}$ for ${ }^{228} \mathrm{Th}$. The mean values inside the Bonin Trench are $0.4 \mathrm{dpm} 10^{-3} \mathrm{~L}$ for ${ }^{231} \mathrm{~Pa}, 1.5 \mathrm{dpm} 10^{-3} \mathrm{~L}$ for ${ }^{227} \mathrm{Ac}$, and $125 \mathrm{dpm} 10^{-3} \mathrm{~L}$ for ${ }^{210} \mathrm{~Pb}$. Some $\mathrm{Th}$ and ${ }^{227} \mathrm{Ac}$ results were also reported previously together with their geochemical implications $[34,35]$.

The activities of ${ }^{90} \mathrm{Sr}\left(\mathrm{t}_{1 / 2}=29 \mathrm{y}\right)$ and ${ }^{137} \mathrm{Cs}\left(\mathrm{t}_{1 / 2}=30 \mathrm{y}\right)$ were found only in the upper water column. The deep waters below $1500 \mathrm{~m}$ contained insignificant amounts of these two nuclides, although ${ }^{137} \mathrm{Cs}$ often showed a positive sign of its presence in the deep water (table I). On the other hand, Pu was detected throughout the water column. The highest Pu activities were observed between 
Table III. The activities of Th isotopes and artificial radionuclides in the water column of the Japan Trench.

\begin{tabular}{ccccccc}
\hline $\begin{array}{c}\text { Depth } \\
(\mathbf{m})\end{array}$ & $\begin{array}{c}\text { Th-232 } \\
\mathbf{d p m} / \mathbf{1 0 0 0 L}\end{array}$ & $\begin{array}{c}\text { Th-230 } \\
\mathbf{d p m} / \mathbf{1 0 0 0 L}\end{array}$ & $\begin{array}{c}\text { Th-228 } \\
\mathbf{d p m} / \mathbf{1 0 0 0 L}\end{array}$ & $\begin{array}{c}\text { Sr-90* } \\
\mathbf{d p m} / \mathbf{1 0 0 0 L}\end{array}$ & $\begin{array}{c}\text { Cs-137 } \\
\mathbf{d p m} / \mathbf{1 0 0 0 L}\end{array}$ & $\begin{array}{c}\text { Pu-239,240 } \\
\mathbf{d p m} / \mathbf{1 0 0 0 L}\end{array}$ \\
\hline 10 & $0.03 \pm 0.02$ & $0.05 \pm 0.04$ & $1.88 \pm 0.16$ & $119 \pm 17$ & $286 \pm 10$ & $0.28 \pm 0.06$ \\
98 & $0.06 \pm 0.03$ & $0.11 \pm 0.05$ & $3.21 \pm 0.23$ & $\mathrm{ND}$ & $157 \pm 4.8$ & $0.69 \pm 0.08$ \\
196 & $0.05 \pm 0.02$ & $0.18 \pm 0.06$ & $4.57 \pm 0.31$ & $110 \pm 9$ & $166 \pm 5.3$ & $0.67 \pm 0.07$ \\
400 & $0.05 \pm 0.02$ & $0.23 \pm 0.05$ & $2.22 \pm 0.15$ & ND & $95 \pm 2.6$ & $1.38 \pm 0.14$ \\
750 & $0.04 \pm 0.02$ & $0.24 \pm 0.06$ & $1.31 \pm 0.14$ & $33 \pm 6$ & $26 \pm 2.2$ & $1.61 \pm 0.44$ \\
1193 & $0.09 \pm 0.03$ & $0.38 \pm 0.08$ & $0.94 \pm 0.14$ & $9 \pm 4$ & $4.8 \pm 1.5$ & $0.78 \pm 0.07$ \\
1686 & $0.07 \pm 0.03$ & $0.33 \pm 0.07$ & $0.69 \pm 0.12$ & ND & $2.4 \pm 1.3$ & $0.44 \pm 0.07$ \\
2472 & $0.04 \pm 0.02$ & $0.47 \pm 0.07$ & $0.40 \pm 0.08$ & $3 \pm 4$ & $2.6 \pm 1.8$ & $0.48 \pm 0.06$ \\
3460 & $0.04 \pm 0.02$ & $0.79 \pm 0.12$ & $0.47 \pm 0.14$ & ND & $2.6 \pm 1.8$ & $0.34 \pm 0.15$ \\
4476 & $0.02 \pm 0.02$ & $1.19 \pm 0.14$ & $0.79 \pm 0.15$ & $5 \pm 4$ & $4.8 \pm 2.2$ & $0.24 \pm 0.04$ \\
5470 & $0.03 \pm 0.02$ & $0.86 \pm 0.15$ & $1.10 \pm 0.20$ & ND & $2.0 \pm 1.8$ & $0.76 \pm 0.07$ \\
6422 & $0.03 \pm 0.02$ & $1.39 \pm 0.14$ & $2.30 \pm 0.19$ & $11 \pm 4$ & $0.7 \pm 1.8$ & $0.75 \pm 0.06$ \\
7565 & $0.02+0.02$ & $1.48+0.15$ & $2.44 \pm 0.22$ & $0 \pm 2$ & $0.0 \pm 1.8$ & $0.76+0.04$ \\
\hline
\end{tabular}

*ND = not determined.

$500 \mathrm{~m}$ and $750 \mathrm{~m}$ and the second highest values were found inside the trenches. The waters within the Japan and Izu-Ogasawara trenches contained $\mathrm{Pu}$ on average of $0.76 \pm 0.05 \mathrm{dpm} 10^{-3} \mathrm{~L}$ and $0.30 \pm 0.06 \mathrm{dpm} 10^{-3} \mathrm{~L}$, respectively. We also note anomalously high values of $\mathrm{Pu}$ at $4964 \mathrm{~m}$, and at the closest to the bottom in the Bonin Trench (table I). The former is not well understood at present. The near-bottom value was probably caused by resuspended sediment particles, as deduced from the high concentration of ${ }^{232} \mathrm{Th}$ (table I). Excluding this value, $\mathrm{Pu}$ is rather homogeneously distributed within the trenches.

\subsection{Particulate data}

The Th isotope results obtained for suspended particles were reported in Nozaki et al. [35]. Here, the ${ }^{231} \mathrm{~Pa}$ data together with ${ }^{230} \mathrm{Th}$ are given in table $I V$. Although the uncertainties of these measurements are large, the results show that the particulate ${ }^{231} \mathrm{~Pa}$ is only less than $5 \%$ of the total (table I) and seems to have a broad mid-depth maximum at around a depth of $3000 \mathrm{~m}$.

The elemental and radiochemical data obtained for settling particulate matter collected by the sediment-trap experiments will be given elsewhere together with their geochemical implications. Here, we report only the mean activities of radionuclides in the settling particles collected at $\sim 5000 \mathrm{~m}$ and $8800 \mathrm{~m}$ depths as necessary for the arguments (table $V$ ). Very high ${ }^{210} \mathrm{~Pb}$ activities were observed in the particles due to scavenging in the water column. The activities of scavenged nuclides, ${ }^{230} \mathrm{Th}$ and ${ }^{231} \mathrm{~Pa}$ also show significant increase with depth. Artificial

Table IV. ${ }^{23 !} \mathrm{Pa}$ and ${ }^{230} \mathrm{Th}$ in suspended particulate matter obtained by in situ filtration.

\begin{tabular}{|c|c|c|c|c|}
\hline Station & $\begin{array}{c}\text { Depth } \\
\text { (m) }\end{array}$ & $\begin{array}{c}{ }^{230} \mathrm{Th}^{*} \\
\mathrm{dpm} / 1000 \mathrm{~L}\end{array}$ & $\begin{array}{c}{ }^{231} \mathrm{~Pa} \\
\mathrm{dpm} / 1000 \mathrm{~L}\end{array}$ & $\begin{array}{c}{ }^{230} \mathrm{Th} /{ }^{231} \mathrm{~Pa} \\
\text { activity ratio }\end{array}$ \\
\hline & \multicolumn{4}{|c|}{ Bonin Trench } \\
\hline \multirow[t]{6}{*}{ An-1 } & 1100 & $0.054 \pm 0.009$ & $0.011 \pm 0.004$ & $4.9 \pm 2.0$ \\
\hline & 2200 & $0.080 \pm 0.037$ & $0.025 \pm 0.015$ & $3.2 \pm 2.4$ \\
\hline & 3300 & $0.187 \pm 0.031$ & $0.029 \pm 0.008$ & $6.4 \pm 2.1$ \\
\hline & 4400 & $0.157 \pm 0.031$ & $0.017 \pm 0.004$ & $9.2 \pm 2.8$ \\
\hline & 5500 & $0.257 \pm 0.075$ & $0.015 \pm 0.002$ & $17 \pm 5$ \\
\hline & \multicolumn{4}{|c|}{ Japan Trench } \\
\hline \multirow[t]{5}{*}{$\mathrm{AN}-4$} & 1100 & $0.068 \pm 0.017$ & $0.010 \pm 0.004$ & $6.8 \pm 3.2$ \\
\hline & 2200 & $0.073 \pm 0.010$ & $0.020 \pm 0.004$ & $3.7 \pm 0.9$ \\
\hline & 3300 & $0.097 \pm 0.023$ & $0.028 \pm 0.007$ & $3.5 \pm 1.2$ \\
\hline & 4400 & $0.188 \pm 0.014$ & $0.014 \pm 0.002$ & $13 \pm 2$ \\
\hline & 5500 & $0.202 \pm 0.024$ & $0.013 \pm 0.002$ & $16 \pm 3$ \\
\hline
\end{tabular}

\footnotetext{
*After Nozaki et al. (1987).
} 
Table V. Nuclide activity and the activity ratio in sediment-trap particles at the JT site.

\begin{tabular}{ccc}
\hline Trap depth & $\mathbf{5 0 0 0} \mathbf{~}$ & $\mathbf{8 8 0 0} \mathbf{~ m}$ \\
\hline${ }^{232} \mathrm{U}(\mathrm{dpm} / \mathrm{g})$ & $1.24 \pm 0.25$ & $1.26 \pm 0.27$ \\
${ }^{232} \mathrm{Th}(\mathrm{dpm} / \mathrm{g})$ & $1.12 \pm 0.26$ & $2.34 \pm 0.61$ \\
${ }^{230} \mathrm{Th}(\mathrm{dpm} / \mathrm{g})$ & $8.9 \pm 1.9$ & $19.0 \pm 3.8$ \\
${ }^{228} \mathrm{Th}(\mathrm{dpm} / \mathrm{g})$ & $12.8 \pm 1.9$ & $14.3 \pm 2.9$ \\
${ }^{231} \mathrm{~Pa}(\mathrm{dpm} / \mathrm{g})$ & $0.55 \pm 0.11$ & $1.46 \pm 0.25$ \\
${ }^{210} \mathrm{~Pb}(\mathrm{dpm} / \mathrm{g})$ & $970 \pm 190$ & $1550 \pm 330$ \\
${ }^{239,240} \mathrm{Pu}(\mathrm{dpm} / \mathrm{g})$ & $0.28 \pm 0.03$ & $0.36 \pm 0.09$ \\
${ }^{237} \mathrm{Cs}(\mathrm{dpm} / \mathrm{g})$ & - & $2.41 \pm 0.64$ \\
$\left.{ }^{230} \mathrm{Th} /{ }^{231} \mathrm{~Pa}\right)$ & 16 & 13 \\
${ }^{\left({ }^{210} \mathrm{~Pb} /{ }^{230} \mathrm{Th}\right)}$ & 109 & 82 \\
$\left.{ }^{239,240} \mathrm{Pu} /{ }^{137} \mathrm{Cs}\right)$ & - & 0.15 \\
\hline
\end{tabular}

radionuclides, $\mathrm{Pu}$ and ${ }^{137} \mathrm{Cs}$ were also detected in the samples, indicating that they are very rapidly transported to the deep sea in association with particulate matter.

\subsection{Heavy metals}

The concentrations of heavy metals for water samples from station AN-1 in the Bonin Trench were determined at Hiroshima University. Since the waters were not filtered, the data represent total acid-soluble concentrations. Vanadium shows some depletion in the surface water, whereas it is almost constant with depth in the deep water. The concentrations of $\mathrm{Cd}, \mathrm{Ni}$, and $\mathrm{Zn}$ increase from the surface to the depth of $\sim 2000 \mathrm{~m}$ where they reach maxima, and then gradually decrease with depth. Surface concentrations for $\mathrm{Zn}$ and $\mathrm{Cd}$ are nearly zero, consistent with phosphate, nitrate, and reactive silica (figure 2). Nickel deviates from this, showing the definitely non-zero surface concentration of $2.8 \mathrm{nmol} \mathrm{kg}$. Copper shows rather monotonic increase with depth, having no mid-depth maximum. Details of these heavy metal profiles will be discussed later.

\section{DISCUSSION AND CONCLUSION}

\subsection{Vertical profiles of anthropogenic nuclides}

The vertical profiles ${ }^{90} \mathrm{Sr}$ and ${ }^{137} \mathrm{Cs}$ (figure 3) show the decreasing trends with depth, which are common features of bomb-produced soluble nuclides such as ${ }^{3} \mathrm{H}$ and ${ }^{14} \mathrm{C}$. The total amount of ${ }^{90} \mathrm{Sr}$ and ${ }^{137} \mathrm{Cs}$ present in the water column is approximately two times higher at the AN-1 site than at the AN-4 site, this difference probably being due to the lateral redistribution of the nuclides along with the gyre circulation, as demonstrated for bomb-produced ${ }^{14} \mathrm{C}$ [6]. Although the distribution patterns of ${ }^{90} \mathrm{Sr}$ and ${ }^{137} \mathrm{Cs}$ in the water column are similar, the two nuclides show some difference in their oceanic behaviour. $\mathrm{Sr}$ exists in sca water as a soluble ionic form of $\mathrm{Sr}^{2+}$. Therefore, ${ }^{90} \mathrm{Sr}$ has not been detected in marine particulate matter or sediments at a significant level, although it may be incorporated in biogenic tests such as carbonates and sulfates. In contrast, ${ }^{137} \mathrm{Cs}$ can be found in various lake and marine sediments. For example, Yang et al. [46] measured the ${ }^{137} \mathrm{Cs}$ and ${ }^{239},{ }^{240} \mathrm{Pu}$ profiles in North Pacific deep-sea sediments to estimate the particle mixing rates due to bioturbation. More directly, ${ }^{137} \mathrm{Cs}$ is also found in settling particulate matter collected by sediment trap in the water column of the Bonin Trench (table $V$ ). The particle reactive nature is not expected from the ionic form of $\mathrm{Cs}^{+}$in sea water, but it seems likely that ${ }^{137} \mathrm{Cs}$ is incorporated into clay minerals by adsorption or through ionic exchange.

The unique behaviour of $\mathrm{Pu}$ isotopes in the marine environment has been demonstrated by previous workers [4, $11,23]$. Unlike ${ }^{137} \mathrm{Cs}$ and ${ }^{90} \mathrm{Sr}$, the $\mathrm{Pu}$ concentration is detectable throughout the water column. In the North Pacific, the ${ }^{239 .}{ }^{240} \mathrm{Pu}$ activity in the surface water is very low, increasing to a mid-depth maximum around 500 to $800 \mathrm{~m}$ and then decreasing with depth. The vertical profiles often show a secondary maximum near the bottom. Our Pu profiles in the upper water column (figure 3) are quite similar to those reported previously for the western North Pacific [4, 23], showing a maximum around $750 \mathrm{~m}$ at both locations. The low ${ }^{239}, 240 \mathrm{Pu}$ activities in the surface waters are probably due to intensive scavenging by particulate matter. This is more likely to occur if $\mathrm{Pu}$ exists in the forms of reduced state such as $\mathrm{Pu}(\mathrm{OH})_{3}^{+}$and $\mathrm{Pu}(\mathrm{OH})_{4}{ }_{4}$. The subsurface ${ }^{239},{ }^{240} \mathrm{Pu}$ maximum may be explained by the vertical transport of $\mathrm{Pu}$ associated with settling particles and subsequent release of $\mathrm{Pu}$ from the particulate matter to the water. This mechanism may involve breakdown of large organic-rich particles bearing $\mathrm{Pu}$ into small particles and remineralization of $\mathrm{Pu}$ into the water. Since $\mathrm{Pu}(\mathrm{VI})$ appears to be a more stable form than $\mathrm{Pu}(\mathrm{IV})$ in sea water by forming plutonyl carbonate complex [17], a change in oxidation state of $\mathrm{Pu}$ along with degradation of particles may also be involved in the formation of subsurface Pu maximum.

Noteworthy in figure 3 is that the waters inside the trench valley have higher activities of $\mathrm{Pu}(0.76$ and 0.30 
dpm $10^{-3} \mathrm{~L}$, respectively for the Japan and Bonin trenches) than most waters above. Such was found in the Aleutian trench by Bowen et al. [4] who obtained the mean $\mathrm{Pu}$ value of $1.1 \pm 0.2 \mathrm{dpm} 10^{-3} \mathrm{~L}$ from $6000 \mathrm{~m}$ to $7200 \mathrm{~m}$ there during the 1973 GEOSECS expedition. The high activities of $\mathrm{Pu}$ in the trench waters probably occur by lateral transport and entry into the trench of Pu-rich bottom waters along isopycnal surface from the adjacent abyssal plain, where release of $\mathrm{Pu}$ is taking place due to oxidation of rapidly sinking, large organic-rich particles at the sediment-water interface [10]. The sediment-trap particles collected at $\sim 8800 \mathrm{~m}$ of the JT site (figure 1 ) between September 1986 and February 1988 contained $0.2-0.5 \mathrm{dpm} \mathrm{g}^{-1}$ for ${ }^{239,}{ }^{240} \mathrm{Pu}$ (table V). Thus, the observed variation of $\mathrm{Pu}$ activity in the trench waters (more than a factor of 3) is in all likelihood dependent upon the vertical particulate flux of $\mathrm{Pu}$ which is carried by large particles such as marine snow and fecal pellets, and hence the surface ocean productivity. The difference in the Pu activity inside the trenches of the above three locations qualitatively agrees with the knowledge of phytoplankton productivity.

Although various implications are possible for the shallow Pu maximum as described above, it is likely to occur by vertical transport of slowly sinking, smaller-sized particles that escaped repackaging through biological mediation. The maximum value of $1.6 \mathrm{dpm} 10^{-3} \mathrm{~L}$ at the $\mathrm{AN}-4$ station is a factor of two to three lower than that at the $\mathrm{AN}-1$ site (figure 3), and it is also low compared with those at the GEOSECS stations from the mid-latitudes of the North Pacific [4]. This may be ascribed to the intense removal of Pu from the surface water at the AN-4 site by large particles under the high-particle flux regime.

\subsection{Depth profiles of Th isotopes}

Because of its long half-life of $1.4 \times 10^{10}$ years and non-radiogenic origin, ${ }^{232}$ Th can be regarded as one of the reactive heavy metals whose concentrations in sea water are extremely low due to removal by particle scavenging. For the determination of ${ }^{232} \mathrm{Th}$ in sea water, more sensitive and precise methods than the $\alpha$-spectrometry used here have recently been developed using thermal ionization mass spectrometry [8, 14]. Application of this method gave a variety of concentrations of ${ }^{232} \mathrm{Th}$, depending on the locations where sea water samples were obtained. Roy-Barman et al. [39] obtained the lowest values around $16 \mathrm{pg} \mathrm{kg}^{-1}$ for dissolved ${ }^{232} \mathrm{Th}$ corresponding to $\sim 0.005 \mathrm{dpm} 10^{-3} \mathrm{~L}$ in the central North Pacific. In Sagami
Bay near Japan, Ida [15] reported dissolved ${ }^{232}$ Th concentrations of $\sim 200 \mathrm{pg} \mathrm{kg}^{-1}$ with a mean activity of $\sim 0.06 \mathrm{dpm} 10^{-3} \mathrm{~L}$. Our acid-soluble ${ }^{232} \mathrm{Th}$ data in the upper water column are comparable with or higher than dissolved ${ }^{232} \mathrm{Th}$ in Sagami Bay. Somewhat higher ${ }^{232} \mathrm{Th}$ activity in shallow waters than in deep waters (figures $4 a, b$ ) suggests that ${ }^{232} \mathrm{Th}$ exhibits the scavenged type distribution like $\mathrm{Al}$ and $\mathrm{Ce}$, showing decrease with depth [36]. However, this must be confirmed by thermal ionization mass spectrometry in the future.

The profiles of ${ }^{230} \mathrm{Th}\left(\mathrm{t}_{1 / 2}=75200 \mathrm{y}\right)$ and ${ }^{228} \mathrm{Th}\left(\mathrm{t}_{1 / 2}=1.9 \mathrm{y}\right)$ down to $6000 \mathrm{~m}$ (figure 4) show marked features which are similar to those in the North Pacific reported by Nozaki et al. [30, 33] The monotonic increase of ${ }^{230} \mathrm{Th}$ concentration with depth is explained as a consequence of a constant ${ }^{230} \mathrm{Th}$ production by ${ }^{234} \mathrm{U}$ decay throughout the water column and the reversible scavenging of Th by particulate matter which settles downward $[1,33,35]$. Luo et al. [20] have shown that the ${ }^{230} \mathrm{Th}$ distribution in the water column is strongly affected by the surface ocean productivity. During the JGOFS EqPac study, the ${ }^{230} \mathrm{Th}$ concentration was systematically lower under the high productivity (and hence high-particle-flux) regime than in the low-particle-flux regime. Such a seasonal variation in the ${ }^{230} \mathrm{Th}$ profiles is consistent with the results obtained for the vertical flux of ${ }^{230} \mathrm{Th}$ by sediment-trap experiments. For example, Bacon et al. [3] found a marked seasonality in the ${ }^{230} \mathrm{Th}$ flux in the deep Sargasso Sea, corresponding to the variation in surface ocean productivity. Thus, somewhat lower concentrations of ${ }^{230} \mathrm{Th}$, and possibly also ${ }^{232} \mathrm{Th}$, for the same depth horizons at AN-4 compared to those at AN-1 may be attributable to the difference in the surface ocean productivity of the two locations.

Unlike ${ }^{230} \mathrm{Th}$, the ${ }^{228} \mathrm{Th}$ profile, due to its relatively short half-life, is largely governed by its source distribution, namely decay of ${ }^{228} \mathrm{Ra}\left(\mathrm{t}_{1 / 2}=5.7 \mathrm{y}\right)$. The ${ }^{228} \mathrm{Ra}$ typically shows higher concentrations in the surface waters due to lateral transport of excess ${ }^{228} \mathrm{Ra}$ (relative to ${ }^{232} \mathrm{Th}$ ) from the shelf and coastal zones, and also in the bottom waters due to diffusion from sediment pore water.

Once inside the trench valley, the ${ }^{230} \mathrm{Th}$ and ${ }^{228} \mathrm{Th}$ activities do not follow the increasing trends with depth which continue from mid depths down to $\sim 6000 \mathrm{~m}$. They show some scatter, particularly in the Bonin Trench (figure 4a), but no systematic trend with depth. The question is whether this scatter of ${ }^{230} \mathrm{Th}$ and ${ }^{228} \mathrm{Th}$ data within the trench is significant. We examined the consistency of Th isotope data together with other nuclides $\left({ }^{231} \mathrm{~Pa},{ }^{210} \mathrm{~Pb}\right.$, 

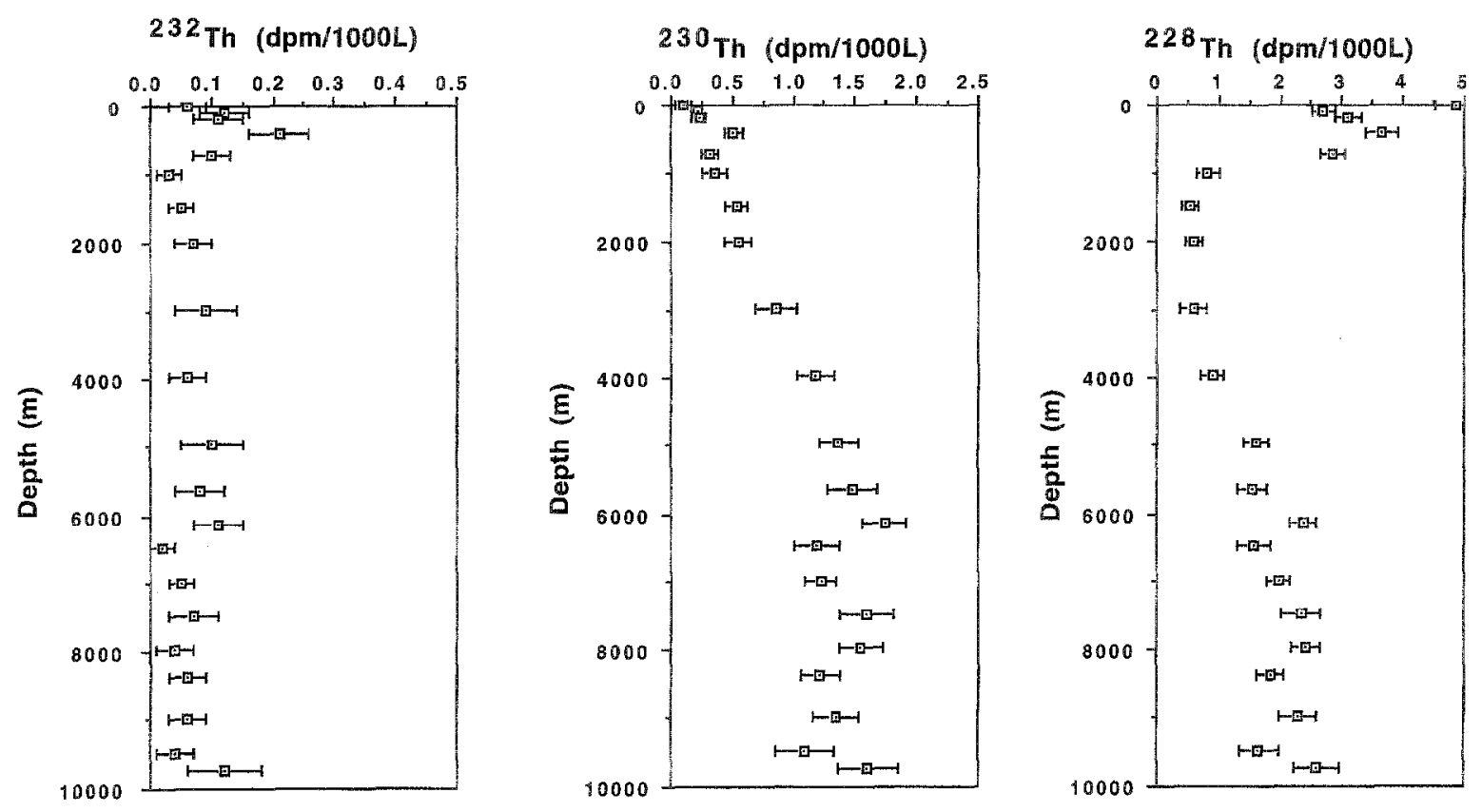

(a)
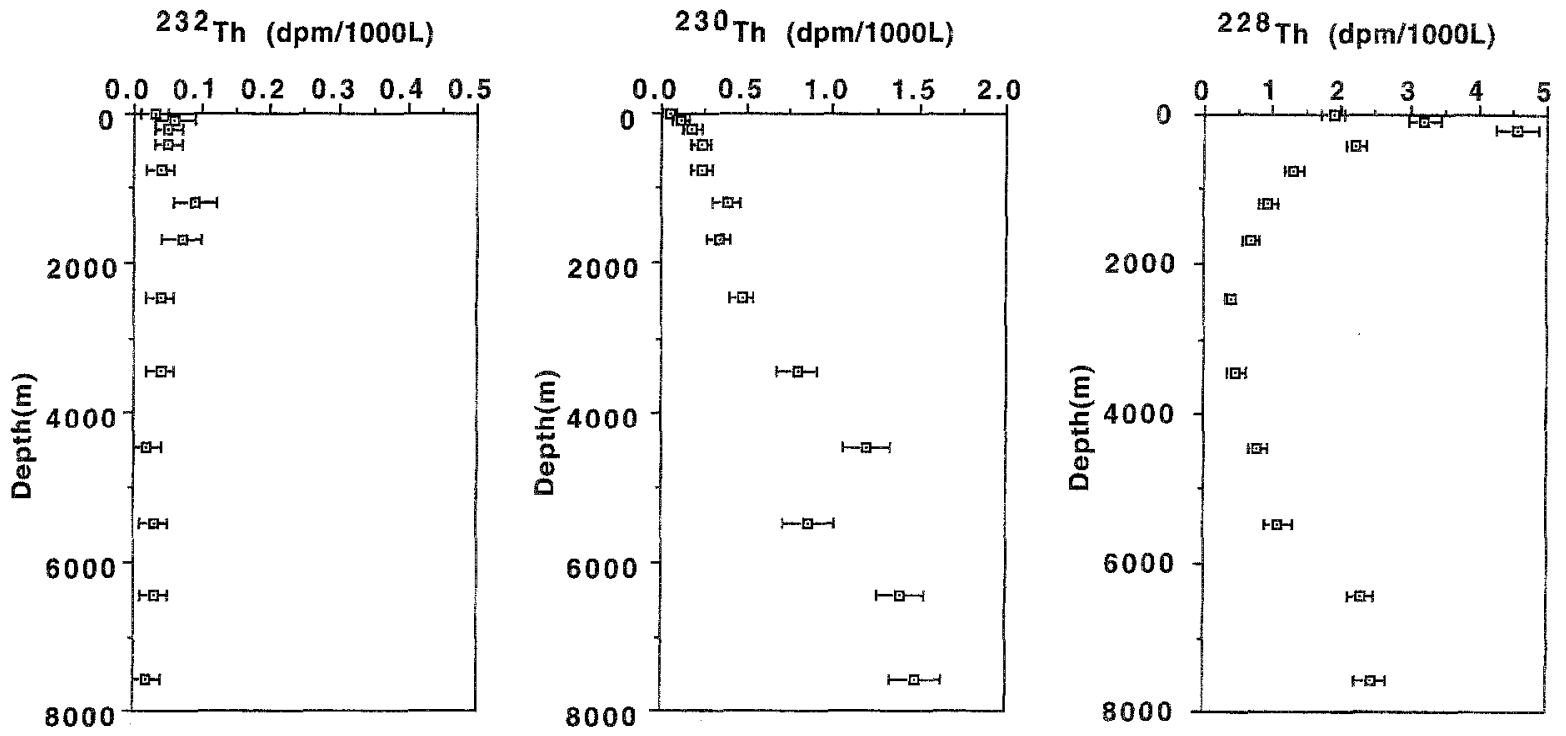

(b)

Figure 4. Vertical profiles of Th isotopes in unfiltered water at stations $\mathrm{AN}-1$ (a) and $\mathrm{AN}-4$ (b). 
${ }^{227} \mathrm{Ac}$, and $\mathrm{Pu}$ isotopes) and chemical constituents (nutrients and trace metals) in terms of possible scavenging and water renewal processes. However, since there is no consistency among those radionuclides and other chemical properties, we regard this scaller of Th dald as an experimental phenomenon rather than real.

\subsection{Vertical profiles of ${ }^{211} \mathrm{~Pa},{ }^{227} \mathrm{Ac}$ and ${ }^{210} \mathrm{~Pb}$}

The data of ${ }^{231} \mathrm{~Pa}\left(\mathrm{t}_{1 / 2}=32800 \mathrm{y}\right),{ }^{227} \mathrm{Ac}\left(\mathrm{t}_{1 / 2}=21.7 \mathrm{y}\right)$, and ${ }^{210} \mathrm{~Pb}\left(\mathrm{t}_{1 / 2}=22.3 \mathrm{y}\right)$ at station $\mathrm{AN}-1$ are plotted in figure 5 . In general, the profiles of these nuclides from the surface to $\sim 6000 \mathrm{~m}$ are similar to those in other locations of the western North Pacific [28]. The activity of ${ }^{231} \mathrm{~Pa}$ is less than $1 \%$ of the activity of its parent, ${ }^{235} \mathrm{U}$, throughout the water column owing to scavenging by particulate matter. The increase of ${ }^{231} \mathrm{~Pa}$ from the surface to the mid-depth concentration of $\sim 0.5 \mathrm{dpm} 10^{-3} \mathrm{~L}$ is similar to those in the western North Pacific [30|. Although a simple box model does not specify the mechanism of supplying to and removing from the ocean, it is useful to describe the overall mean residence times of elements [27]. For a soluble parent and reactive daughter pair, the mean residence time of the daughter $\left(\tau_{d}\right)$ is given by,

$$
\tau_{\mathrm{d}}=\left(\frac{\mathrm{R}}{1-\mathrm{R}}\right) \frac{1}{\lambda_{\mathrm{d}}}
$$

where $\mathrm{R}$ is the mean activity ratio of the daughter to the parent, and $\lambda_{d}$ is the half-life of the daughter. Taking
$0.4 \mathrm{dpm} 10^{-3} \mathrm{~L}$ as the mean ${ }^{231} \mathrm{~Pa}$ activity throughout the water column, the box-model scavenging residence time of ${ }^{231} \mathrm{~Pa}$ is estimated as 180 years. The ${ }^{231} \mathrm{~Pa}$ residence time is longer than that of ${ }^{230} \mathrm{Th}(\sim 30 \mathrm{y}[33])$.

The profile of ${ }^{210} \mathrm{~Pb}$ resembles that of ${ }^{231} \mathrm{~Pa}$, showing a mid-depth maximum around $3000 \mathrm{~m}$. The ${ }^{210} \mathrm{~Pb}$ activity in the deep waters is only half to one third of its precursor ${ }^{226} \mathrm{Ra}\left(\sim 350 \mathrm{dpm} 10^{-3} \mathrm{~L}\right)$, indicating removal of ${ }^{210} \mathrm{~Pb}$ by particle scavenging. The estimated ${ }^{210} \mathrm{~Pb}$ box-model residence time is relatively short at $\sim 30 \mathrm{y}$, however. There are nearby GEOSECS stations and R/V Hakuho-Maru stations in the western North Pacific where the ${ }^{210} \mathrm{~Pb}$ data are available. At most of the stations, the estimated ${ }^{210} \mathrm{~Pb}$ residence times are around 100 years [36], decreasing from the center of the North Pacific gyre to the continental margins. In particular, the ${ }^{210} \mathrm{~Pb}$ residence times in regions close to the boundary (e.g., Manus Basin and the Bering Sea) are extremely short. The present ${ }^{210} \mathrm{~Pb}$ data suggests that a rapid transition in the deep-sea ${ }^{210} \mathrm{~Pb}$ residence time occurs near the continental slope.

The activity of ${ }^{227} \mathrm{Ac}$, a daughter nuclide of ${ }^{231} \mathrm{~Pa}$, is higher than its parent activities, particularly in the deep waters below $3000 \mathrm{~m}$. This excess ${ }^{227} \mathrm{Ac}$ is presumably transported by eddy diffusion from the underlying sediments, very much as in the case of ${ }^{228} \mathrm{Ra}$ [21]. This is in agreement with previous findings in the deep water of the North Pacific [24] and in the interstitial water of a deep-sea sediment core [34].
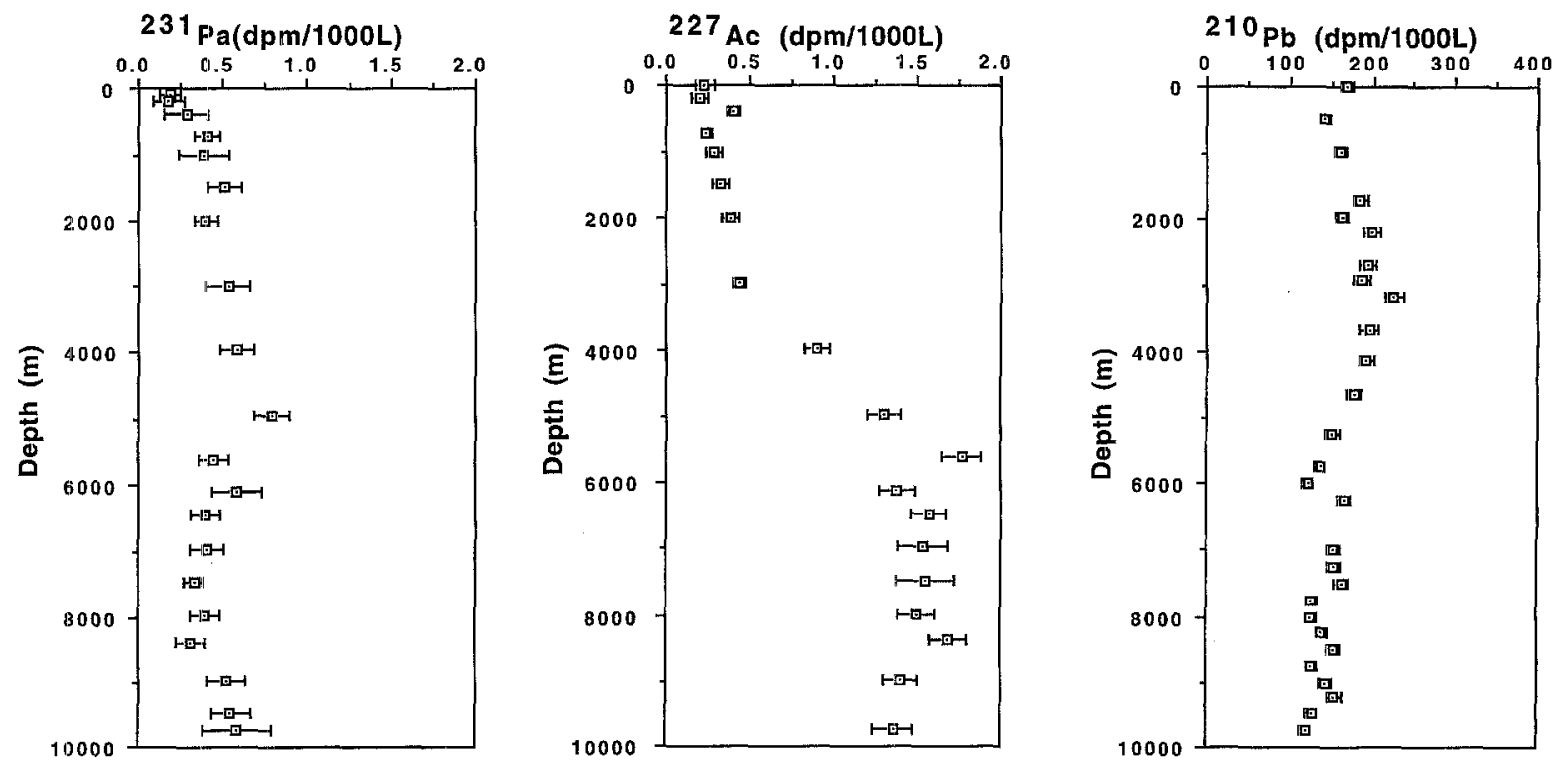

Figure 5. Vertical profiles of ${ }^{231} \mathrm{~Pa},{ }^{227} \mathrm{Ac}$, and ${ }^{210} \mathrm{~Pb}$ in unfiltered water at station $\mathrm{AN}-1$. 
It is apparent in the three profiles shown in figure 5 that there is no systematic trend in the activities at depths of below $6000 \mathrm{~m}$. This is consistent with the distribution of Th isotopes. The uniformity of each nuclide in the trench water is presumably due to rapid vertical mixing of water within the trench.

\subsection{Heavy metals}

The vertical profiles of $\mathrm{V}, \mathrm{Zn}, \mathrm{Cd}, \mathrm{Cu}, \mathrm{Mn}$, and $\mathrm{Ni}$ at station AN-1 are shown in figure 6. The profile of V, showing slightly lower concentrations in the upper part of the water column than in deep waters, obtained here agrees with that of Collier [9] for the eastern North Pacific. Cd, $\mathrm{Ni}$, and $\mathrm{Zn}$ show the nutrient-type distributions as already demonstrated by Bruland [7], who has also shown that in the vertical profile, $\mathrm{Cd}$ resembles phosphate and nitrate, whereas $\mathrm{Zn}$ resembles reactive silica. The two patterns cannot be distinguished from our data because $\mathrm{Zn}$ and $\mathrm{Cd}$ at the $\mathrm{AN}-1$ site are very well correlated with each other $\left(\mathrm{r}^{2}=0.96\right)$.

Although the Cu concentration also increases with depth, the vertical pattern is discernibly different from those of $\mathrm{Cd}, \mathrm{Zn}$, and $\mathrm{Ni}$. The copper shows a depth-profile of rather monotonic increase, with no mid-depth maximum. This deviation from the nutrient-type profile is attributed to the high affinity of $\mathrm{Cu}$ with respect to scavenging by particles [5]. Manganese also has a unique profile, showing a sub-surface maximum associated with the oxygen minimum layer (figure 6). This Mn profile is similar to that reported by Landing and Bruland [18] for the eastern North Pacific. Because the Mn data below $6000 \mathrm{~m}$ are scattered, it is difficult to draw a real trend from the data.

For all other heavy metals execpt for $\mathrm{Mn}$, the vertical profiles are continuous down to the trench bottom, and there
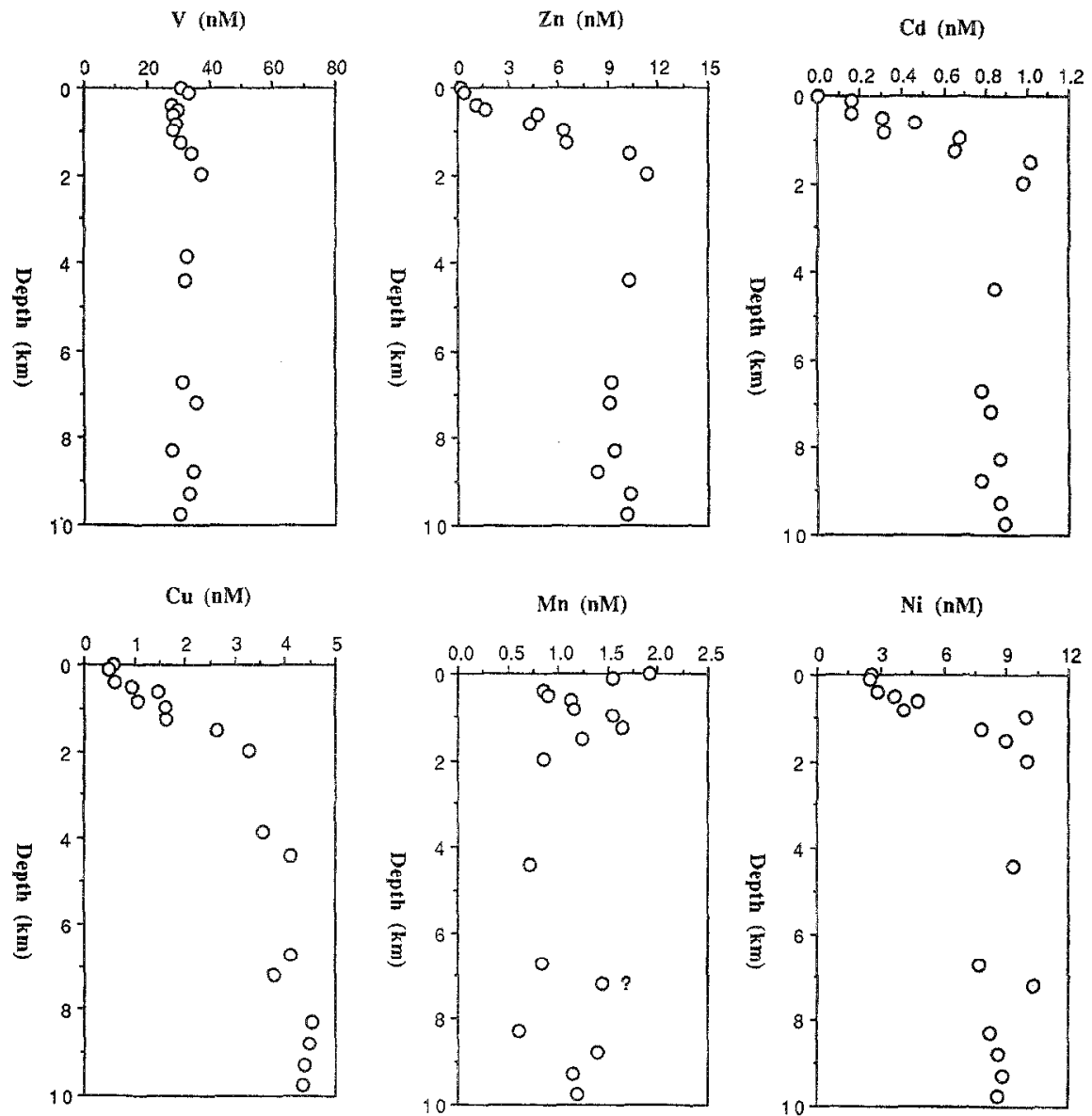

Figure 6. Vertical profiles of $\mathrm{V}, \mathrm{Zn}, \mathrm{Cd}, \mathrm{Cu}, \mathrm{Mn}$, and Ni unfiltered water at the Bonin Trench station AN-1. 
is no evidence that the water inside the trench is chemically different from the overlying water around $6000 \mathrm{~m}$ in depth. This situation in the trench is clearly different from that pertaining in anoxic basins such as the Cariaco Trench and in some Fjords like Saanich Inlet, where the density stratification limits the vertical exchange of water across the pycnocline, and thereby anoxic conditions develop in the deep waters.

\subsection{Renewal of Bonin Trench water}

One of the interesting questions about the trench environment is how rapidly the trench water is renewed. Al first sight, the hydrographic properties (temperature, salinity, dissolved oxygen), the nutrients (figure 2), and trace metal concentrations (figure 6) in the trench waters are not significantly different from those in the bottom water overlying the western Pacific abyssal plain $(\sim 6000 \mathrm{~m}$ in depth), and their depth profiles are nearly constant. This implies that in situ alteration of the chemical composition of sea water is negligible within the trench, and suggests that renewal of the trench water with Northwest Pacific deep water must occur very rapidly. Some constraints on the renewal time may be obtained from the data of dissolved oxygen. In Pacific deep water near the bottom, the GEOSECS ${ }^{14} \mathrm{C}$ and dissolved oxygen data show a linear relationship with a slope corresponding to the oxygen utilization rate of $0.13 \mu \mathrm{mol} \mathrm{kg} \mathrm{kg}^{-1} \mathrm{y}^{-1}$ (figure 7). The con-

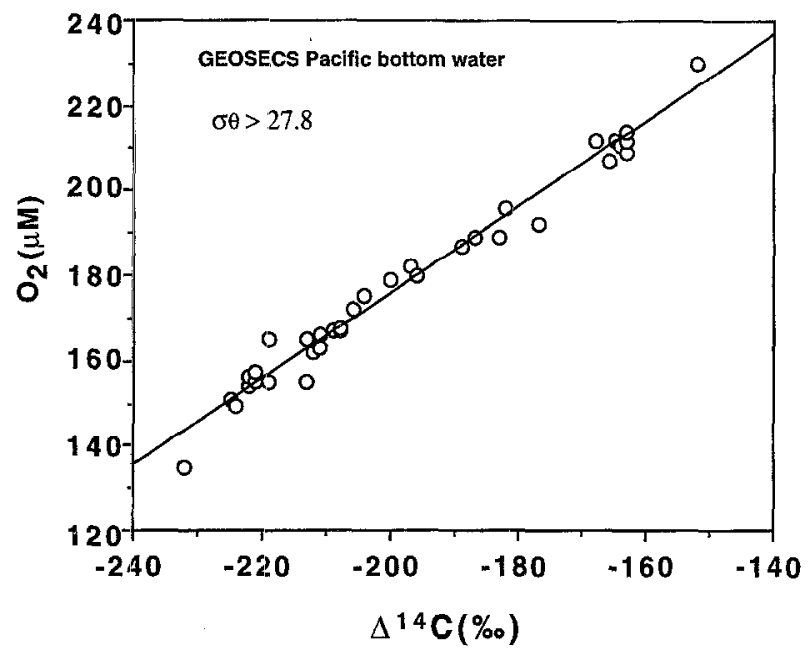

Figure 7. Correlation diagram of dissolved oxygen and $\Delta^{14} \mathrm{C}$ in GEOSECS Pacific bottom waters (Ostlund et al., 1979). Converting the $\Delta^{14} \mathrm{C}$ values to radiocarbon ages, an oxygen consumption rate of $0.13 \mu \mathrm{mol} \mathrm{kg} \mathrm{kg}^{-1}$ is obtained from the slope of the regression line. sumption of dissolved oxygen may take place largely at the sediment-water interface rather than in the water column. Dissolved oxygen inside the trench can only be supplied by replacement of water and it is then consumed along with the residence time of the water. The observed constancy of dissolved oxygen concentration below $6000 \mathrm{~m}$ at stations AN-1 and AN-4 may have an uncertainty of $\sim 5 \mu \mathrm{mol} \mathrm{kg}^{-1}$. Therefore, with the above oxygen utilization rate, the renewal time of water occupying the Japan and Izu-Ogasawara Trenches must be less than 40 years. The physical situations of the giant trenches in the North Pacific are clearly different from that of stratified basins like the Cariaco Trench.

Some radionuclide data are also useful in this context. ${ }^{227} \mathrm{Ac}$ and ${ }^{278} \mathrm{Ra}$ are known to be present in excess due to supply from the underlying sediments $[21,34]$. The ${ }^{227} \mathrm{Ac}$ activity would be higher in the trench water than in the renewal water if additional input came from the walls of the trench. Nevertheless, it is almost vertically constant below $6000 \mathrm{~m}$, and not very different from that of the bottom water overlying the western North Pacific abyssal plain [24]. This suggests that the renewal and vertical mixing of the trench water are rapid compared to the half-life of ${ }^{227} \mathrm{Ac}(21.7 \mathrm{y})$.

${ }^{228} \mathrm{Ra}$ with a half life of 5.7 years can provide better constraints. Although we have not measured ${ }^{228} \mathrm{Ra}$ directly, ${ }^{228} \mathrm{Th}$ may be used to deduce its parent ${ }^{228} \mathrm{Ra}$ activity. The reason for this comes from the box-model type relationship for the concordance of $\left({ }^{228} \mathrm{Th} /{ }^{228} \mathrm{Ra}\right)$ and $\left({ }^{230} \mathrm{Th} /{ }^{234} \mathrm{U}\right)$ ratios [35] given by,

$$
\left(\frac{\mathrm{A}_{\mathrm{Ra}-228}}{\mathrm{~A}_{\mathrm{Th}-228}}\right)=\left(\frac{\lambda_{\mathrm{Th}-230}}{\lambda_{\mathrm{Th}-228}}\right)\left(\frac{\mathrm{A}_{\mathrm{U}-234}}{\mathrm{~A}_{\mathrm{Th}-230}}\right)+1
$$

In deriving equation (2), the first-order scavenging rate constant is assumed to be the same for ${ }^{228} \mathrm{Th}$ and ${ }^{230} \mathrm{Th}$. The measured ${ }^{234} \mathrm{U} /{ }^{230} \mathrm{Th}$ ) for the deep waters is about 2000 , and hence $\left({ }^{228} \mathrm{Th} /{ }^{228} \mathrm{Ra}\right)$ becomes 0.95 , which is close to the equilibrium value.

The ${ }^{228} \mathrm{Th}$ data below $6000 \mathrm{~m}$ at station $\mathrm{AN}-1$ are scattered somewhat from 1.4 to $2.6 \mathrm{dpm} 10^{-3} \mathrm{~L}$. As discussed previously, this scatter may be ascribable to analytical errors, and the values are not significantly different from the mean of $2.0 \mathrm{dpm} 10^{-3} \mathrm{~L}$ at 5624 and $6125 \mathrm{~m}$, within the uncertainty of $\pm 30 \%$. This implies that the Bonin Trench water is replaced on a time scale much shorter than the half-life of ${ }^{228} \mathrm{Ra}(5.7 \mathrm{y})$. If we admit that the 
variation within the trench is real and ascribable solely to decay of ${ }^{228} \mathrm{Ra}$, then an upper limit of about five years is estimated as the time necessary for the trench water to be replaced by the overlying water. This is a conservative estimate, and the same conclusion may be applied to Japan Trench waters (see figure 4b).

Rapid refreshment of the trench waters may be related to the fact that these trenches are located in the western boundary with its prevailing deep currents and the Izu-Ogasawara Ridge and the Japanese Island Chain [44]. Although the deep water circulation below $6000 \mathrm{~m}$ has not as yet been thoroughly investigated, it is likely that the trench water may be flushed by following the prevailing deep current above the trench. However, our findings that the trench water has a uniform density and chemical characteristics similar to those around depths of $6000 \mathrm{~m}$ strongly suggest that the water communicates freely by isopycnal mixing with the bottom water overlying the abyssal plain of the western North Pacific.

\subsection{Effect of Boundary and Bottom Scavenging}

An effect of scavenging at the sediment-water interface was first proposed by Bacon et al. [2], based on the ${ }^{210} \mathrm{~Pb}$ and ${ }^{226} \mathrm{Ra}$ disequilibrium distribution in the North Atlantic. Our ${ }^{210} \mathrm{~Pb}$ profile data at station $\mathrm{AN}-1$, which show a maximum at $3000-4000 \mathrm{~m}$, then a decrease towards the abyssal plain depth $(\sim 6000 \mathrm{~m})$, and constant in the trench water (figure 5), are consistent with boundary and bottom scavenging. ${ }^{231} \mathrm{~Pa}$ shows similar features. In contrast, ${ }^{230} \mathrm{Th}$ increases almost linearly with depth down to $6000 \mathrm{~m}$ and remains constant at somewhat reduced activity than that at $\sim 6000 \mathrm{~m}$. The vertical profile of ${ }^{230} \mathrm{Th}$ is more strongly governed by adsorption/desorption equilibrium and the particle dynamics as described in Nozaki et al. [35], but, in the trench water, the rapid mixing tends to govern the vertical profile as modeled by Rutgers van der Loeff et al. [40] and Scholten et al. [42]. The particle associations of ${ }^{210} \mathrm{~Pb}$ and ${ }^{231} \mathrm{~Pa}$ are about $3-5 \%$, which are significantly lower than that of ${ }^{230} \mathrm{Th}(\sim 20 \%)$. Therefore, ${ }^{210} \mathrm{~Pb}$ and ${ }^{231} \mathrm{~Pa}$ behave differently from ${ }^{230} \mathrm{Th}$ in that they are more strongly influenced by boundary and bottom scavenging, resulting in different water column distributions.

It has been demonstrated that a large-scale fractionation between ${ }^{231} \mathrm{~Pa}$ and ${ }^{230} \mathrm{Th}$ takes place in the pathways from the water column to the sedimentary sink $[19,47] .{ }^{230} \mathrm{Th}$ tends to be removed vertically with its short residence time $(-30 \mathrm{y})$, whereas ${ }^{231} \mathrm{~Pa}$ is less particle-reactive than
${ }^{230} \mathrm{Th}$, and hence is transported, within its oceanic residence time of $\sim 150$ years, to ocean margins where the nuclide is more intensively scavenged under the high-particle-flux regimes. As a result, the ${ }^{230} \mathrm{Th} /{ }^{231} \mathrm{~Pa}$ activity ratios are higher in the oligotrophic central gyre and lower in the eutrophic ocean margins as compared to the value of 10.8 (the production ratio from $U$ decay in sea water). The ${ }^{23 !} \mathrm{Pa}$ and ${ }^{230} \mathrm{Th}$ fractionation also takes place in the trench environment studied here. Figure 8 shows the vertical profile of ${ }^{230} \mathrm{Th} /{ }^{231} \mathrm{~Pa}$ activity ratio at station $\mathrm{AN}-1$. The ${ }^{230} \mathrm{Th} /{ }^{231} \mathrm{~Pa}$ ratio increases from $\sim 1$ in the surface water to $\sim 3$ in the trench water below $6000 \mathrm{~m}$. These activity ratios are significantly lower than 10.8 , and hence, the waters are enriched more in ${ }^{231} \mathrm{~Pa}$ than ${ }^{230} \mathrm{Th}$.

On the other hand, the ${ }^{230} \mathrm{Th} /{ }^{231} \mathrm{~Pa}$ activity ratios of the suspended particles collected by in situ pumps (table IV) are a factor of 3-5 higher than those in sea water for the same depth horizon, and clearly show an increase with depth. Settling particles collected by sediment traps have the ${ }^{230} \mathrm{Th} /{ }^{231} \mathrm{~Pa}$ activily ratios of $16 \pm 5$ at $~ 5000 \mathrm{~m}$ and



Figure 8. Depth profile of ${ }^{230} \mathrm{Th} /{ }^{231} \mathrm{~Pa}$ activity ratio in unfiltered sea water at station AN-1. 
$13 \pm 3$ at $8800 \mathrm{~m}$ (table $V$ ), roughly in agreement with those of suspended particles for similar depths (table IV). Furthermore, the surface sediments collected at the trench bottom of the AN-1 site also gave the mean activities of $16 \mathrm{dpm} \mathrm{g}{ }^{1}$ for ${ }^{230} \mathrm{Th}$ and $1.1 \mathrm{dpm} \mathrm{g}^{-1}$ for ${ }^{231} \mathrm{~Pa}$ and the ${ }^{230} \mathrm{Th} /{ }^{231} \mathrm{~Pa}$ ratio of $15 \pm 3$ [32]. Although the measured vertical flux of ${ }^{20 T} \mathrm{Th}$ at JT site is, on average, some three times greater than that expected from production by ${ }^{234} \mathrm{U}$ decay in the water column, the fact that all the particles and sediments collected from depths greater than $5000 \mathrm{~m}$ have activity ratios greater than or equal to 10.8 implies that the sediments in the trench valley are not acting as an effective sink of ${ }^{231} \mathrm{~Pa}$ over ${ }^{230} \mathrm{Th}$. In contrast, suspended particles collected at depths shallower than $\sim 3000 \mathrm{~m}$ are enriched in ${ }^{231} \mathrm{~Pa}$ over ${ }^{230} \mathrm{Th}$ (table $\mathrm{IV}$ ). This suggests that the shallow-depth and slope sediments may be effectively accumulating ${ }^{231} \mathrm{~Pa}$ over ${ }^{230} \mathrm{I} / \mathrm{h}$ in this western Pacific region.

\section{Acknowledgements}

The authors would like to thank the scientific party of the Antares Expedition, the captain, officers, and crew of the R.V. Ilakuho-Maru for their collaboration and assistance in the sampling. They are also grateful to Dr. G. Henderson and an anonymous reviewer for providing useful comments on the earlier version of the manuscript. They thank Ms. K. Hasegawa for typing the manuscript. This work was supported by the Ministry of Education, Science, Sports and Culture, Japan under the Grant-in-Aids to the University of Tokyo (Y. Nozaki, Principal Investigator).

\section{REFERENCES}

[1] Bacon M.P., Anderson R.F., Distribution of thorium isotopes between dissolved and particulate forms in the deep sea, J. Geophys. Res. 87 (1982) 2045-2056.

[2] Bacon M.P., Spencer D.W., Brewer P.G., ${ }^{210} \mathrm{~Pb} /{ }^{226} \mathrm{Ra}$ and ${ }^{210} \mathrm{Po} /{ }^{210} \mathrm{~Pb}$ disequilibria in sea water and suspended particulate matter, Earth Planet. Sci. Lett. 32 (1976) 277-296.

[3] Bacon M.P., Iluh C.A., Fleer A.P., Deuser W.G., Seasonality in the flux of natural radionuclides and plutonium in the deep Sargasso Sea, Deep-Sea Res. 32 (1985) 273-286.

[4] Bowen V.T., Noshkin V.E., Livingston H.D., Volchok H.L., Fallout radionuclides in the Pacific Ocean: vertical and horizontal distributions, largely from GEOSECS stations, Earth Planet. Sci. Lett. 49 (1980) 411-434.

[5] Boyle E.A., Sclater F., Edmond J.M., The distribution of dissolved copper in the Pacific, Earth Planet. Sci. Lett. 37 (1977) $38-54$.

[6] Broecker W.S., Peng T.H., Ostlund G., Stuiver M., The distribution of bomb radiocarbon in the ocean, J. Geophys. Res. 90 (1985) 6953-6970.

[7] Bruland K.W., Oceanographic distributions of cadmium, zinc, nickel and copper in the North Pacific, Earth Planet. Sci. Lett. 47 (1980) 176-198.

[8] Chen J.H., Edwards R.L., Wasserburg G.J., ${ }^{238}$ U, ${ }^{234} \mathrm{U}$ and ${ }^{232} \mathrm{Th}$ in seawater, Earth Planet. Sci. Lett. 80 (1986) 241-256.

[9] Collier R., Particulate and dissolved vanadium in the North Pacific Ocean, Nature 309 (1984) 441-444.

[10] Fowler S.W., Knauer G.A., Role of large particles in the transport of elements and organic compounds through the oceanic water column, Prog. Oceanogr. 16 (1986) 147-194.

[11] Fowler S.W., Ballestra S., La Rosa J., Fukai R., Vertical transport of particulate-associated plutonium and americium in the upper water column of the Northeast Pacific, Deep-Sea Res. 30 (1983) 1221-1233.

[12] Honjo S., Doherty K.W., Large aperture time-series sediment traps; design objectives, construction and application, Deep-Sea Res. 35 (1988) 133-149.

[13] Horibe Y., Ed. Preliminary Report of the R.V. Hakuho-Maru Cruise KH-68-4 (Southern Cross Expedition), The Ocean Research Institute, University of Tokyo (1970) p. 170.

[14] Huh C.A., Beasley T.M., Profiles of dissolved and particulate thorium isotopes in the water column of coastal Southern Califormia, Earth Planet. Sci. Lett. 85 (1987) 1-10.

[15] Ida M., Determination of Th in seawater by thermal ionization mass spectrometry, Master Thesis, The University of Tokyo (1997) p 70.

[16] Kanamori S., Ed. The distribution and behavior of heavy metals in the occan, Technical Report prepared by the Ministry of Education, Science and Culture, Japan (1985) p. 146.

[17] Li Y.H., Distribution patterns of the elements in the ocean: A synthesis, Geochim. Cosmochim. Acta 55 (1991) 3223-3240.

[18] Landing W.M., Bruland K.W., Manganese in the North Pacific, Earth Planet. Sci. Lett. 49 (1980) 45-56.

[19] Lao Y., Anderson R.F., Broecker W.S., Hofmann H.J., Wolfli W., Particulate fluxes of ${ }^{230} \mathrm{Th},{ }^{231} \mathrm{~Pa}$, and ${ }^{10} \mathrm{Be}$ in the northeastern Pacific Ocean, Geochim. Cosmochim. Acta 57 (1993) $205-217$.

[20] Luo S., Ku T.L., Kusakabe M., Bishop J.K., Yang Y.L., Tracing particle cycling in the upper ocean with ${ }^{230} \mathrm{Th}$ and ${ }^{228} \mathrm{Th}$ : An investigation in the equatorial Pacific along $140^{\circ} \mathrm{W}$, Deep-Sea Res. II 42 (1995) 805-829.

[21] Moore W.S., Oceanic concentration of ${ }^{228} \mathrm{Ra}$, Earth Planet. Sci. Lett. 6 (1969) 437-446. 
[22] Nagaya Y., Nakamura K., Artificial radionuclides in the western Northwest Pacific (I); ${ }^{90} \mathrm{Sr}$ and ${ }^{137} \mathrm{Cs}$ in the deep waters, J. Oceanogr. Soc. Japan, 37 (1981) 135-144.

[23] Nagaya Y., Nakamura K., Artificial radionuclides in the western Northwest Pacific (II): ${ }^{137} \mathrm{Cs}$ and ${ }^{239,230} \mathrm{Pu}$ inventories in water and sediment columns observed from 1980 to 1986 , J. Oceanogr. Soc. Japan 43 (1987) 345-355.

[24] Nozaki Y., Excess ${ }^{227} \mathrm{Ac}$ in deep ocean water, Nature 310 (1984) 486-488.

[25] Nuzaki Y., ${ }^{226} \mathrm{Ra}^{-2}{ }^{22} \mathrm{RnI}^{2}{ }^{210} \mathrm{~Pb}$ systernatics in seawater near the bottom of the ocean, Earth Planet. Sci. Lett. 80 (1986) 36-40.

[26] Nozaki Y., On the oceanographic and environmental study of the trench, Kaiyo Monthly 21 (1989) 187-191.

[27] Nozaki Y., The systematics and kinetics of the U/Th decay series nuclides in ocean water, Rev. Aqua. Sei., 4 (1991) 75-105.

[28] Nozaki Y., Actinium-227: A steady state tracer for the deep-sea basin-wide circulation and mixing studies, in: Deep Ocean Circulation, T. Teramoto, Ed., Llsevier Scientific Publ., Amsterdam (1993) p. 139-156.

[29] Nozaki Y., A fresh look at element distribution in the North Pacific Ocean, EOS trans. AGU, 78 (1997) 221.

[30] Nozaki Y., Nakanishi T., ${ }^{231} \mathrm{~Pa}$ and ${ }^{230} \mathrm{Th}$ profiles in the open ocean water column, Deep-Sea Res. 32 (1985) 1209-1220.

[31] Nozaki Y., Yamada M., Thorium and protactinium isotope distribution in waters of the Japan Sea, Deep-Sea Res. 34 (1987) 1417-1430.

[32] Nozaki Y., Ohta Y., Rapid and frequent turbidite accumulation in the bottom of Izu-Ogasawara Trench: chemical and radiochemical evidence, Farth Planet. Sci. I ett. 120 (1993) $345-360$.

[33] Nozaki Y., Horibe Y., Tsubota H., The water column distributions of thorium isotopes in the western North Pacific, Earth Planet. Sci. Lett. 54 (1981) 203-216.

[34] Nozaki Y., Yamada M., Nikaido H., The marine geochemistry of actinium-227: Evidence for its migration through sediment pore water, Geophys. Res. Lett. 17 (1990) 1933-1936.

[35] Nozaki Y., Yang H.S., Yamada M., Scavenging of thorium in the ocean, J. Geophys. Res. 92 (1987) 772-778.
[36] Nozaki Y., Zhang J., Takeda A., ${ }^{210} \mathrm{~Pb}$ and ${ }^{210} \mathrm{Po}$ in the equatorial Pacific and the Bering Sea: The effects of biological productivity and boundary scavenging, Deep-Sea Res. II (1997) in press.

[37] Ostlund H.G., Brescher R., Oleson R., Ferguson M.J., GEOSECS Pacific Radiocaarbon and Tritium Results (Miamai), R.S.M.A.S. Tritium Laboratory Data Report \#8 (1979) 171 p.

[38] Rowe G.T., Biomass and production of the deep-sea macrobenthos, in: the Sea, Vol. 8., G. T. Rowe, (Ed.), Wiley-Interscience Publ. London (1983) p. 97-121.

[39] Roy-Barman M., Chen J.H., Wasserburg G.J., ${ }^{230} \mathrm{Th}^{232}$ Th systematics in the central Pacific Ocean, Earth Planet. Sci. Letl. 139 (1996) 351-363.

[40] Rutgers van der Loeff M.M., Berger G.W., Scavenging of ${ }^{230} \mathrm{Th}$ and ${ }^{231} \mathrm{~Pa}$ near the Antarctic Polar Front in the South Atlantic, Deep-Sea Res, 40 (1993) 339-357.

[41] Schaule B.K., Patterson C.C., Lead concentrations in the northeast Pacific: evidence for global anthropogenic perturbations, Earth Planet. Sci. Lett. 54 (1981) 97-116.

[42] Schoitten J.C., Rutgers yan der Loeff M.M., Michel A., Distribution of ${ }^{230} \mathrm{Th}$ and ${ }^{231} \mathrm{~Pa}$ in the water column in relation to the ventilation of the deep Arctic basins, Deep-Sea Res. II, 42 (1995) 15191531 .

[43] Shitashima K., The distribution and behavior of heavy metals in the ocean, Ph. D. thesis, Hiroshima University, Hiroshima, Japan (1988) p. 237.

[44] Teramoto T., Eds. Deep Ocean Circulation, Physical and Chemical Aspects, Elsevier Scientific Publ. (1993) p. 382.

[45] The GFOSFCS Operation Group GFOSFCS Atlantic, Pacific and Indian Ocean Expedition, Vol. 7, National Science Foundation, Washington D.C. (1987) p. 200.

[46] Yang H.S., Nozaki Y., Sakai H., Nagaya Y., Nakamura K., Natural and man-made radionuclide distributions in Northwest Pacific deep-sea sediments: rate of sedimentation, bioturbation and ${ }^{226}$ Ra migration, Geochem. J. 20 (1986a) 29-40.

[47] Yang H.S., Nozaki Y., Sakai H., Masuda A., The distribution of ${ }^{230} \mathrm{Th}$ and ${ }^{231} \mathrm{~Pa}$ in the deep-sea surface sediments of the Pacific Ocean, Geochim. Cosmochim. Acta 50 (1986b) 81-89. 